This manuscript is a preprint and has been submitted for publication in Basin Research. Please note that, despite having undergone peer-review, the manuscript has yet to be formally accepted for publication. Subsequent versions of this manuscript may have slightly different content. If accepted, the final version of this manuscript will be available via the 'Peer-reviewed Publication DOI' link on the right-hand side of this webpage. Please feel free to contact any of the authors; we welcome feedback 


\section{Salt thickness and composition influence rift structural style, northern North Sea, offshore Norway}

Christopher A-L. Jackson ${ }^{1 *}$, Gavin M. Elliott ${ }^{1 *}$, Elisabeth Royce-Rogers ${ }^{1 *}$, Rob L. Gawthorpe ${ }^{2}$, Tor E. Aas $^{3}$

( Now at: TGS, 1 The Crescent, Surbiton, Surrey, KT6 4BN, UK

(¥) Now at: Lukoil Overseas UK Ltd, 5-11 Regents Street, London, SW1Y 4LR, UK

$$
\text { *Corresponding author (e-mail: c.jackson@imperial.ac.uk) }
$$

\section{ABSTRACT}

'Salt' giants are typically halite-dominated, although they invariably contain other evaporite (e.g. anhydrite, bittern salts) and non-evaporite (e.g. carbonate, clastic) rocks. Rheological differences between these rocks mean they impact or respond to rift-related, upper crustal deformation in different ways. Our understanding of basin-scale lithology variations in ancient salt giants, what controls this, and how this impacts later riftrelated deformation, is poor, principally due to a lack of subsurface datasets of sufficiently regional extent. Here we use 2D seismic reflection and borehole data from offshore Norway to map compositional variations within the Zechstein Supergroup (Lopingian), relating this to the structural styles developed during Middle Jurassic-to-Early Cretaceous rifting. Based on the proportion of halite, we identify and map four intrasalt depositional zones (sensu Clark et al., 1998) offshore Norway. We show that, at the basin margins, the

30 Zechstein Supergroup is carbonate-dominated, whereas towards the basin centre, it become increasingly 31 halite-dominated, a trend observed in the UK sector of the North Sea Basin and in other ancient salt giants. 32 However, we also document abrupt, large magnitude compositional and thickness variations adjacent to 
footwall highs, whereas thick, halite-dominated successions occur only a few kilometres away in adjacent depocentres. It is presently unclear if this variability reflects variations in syn-depositional relief related to flooding of an underfilled presalt (Early Permian) rift or syn-depositional (Lopingian) rift-related faulting. Irrespective of the underlying controls, variations in salt composition and thickness influenced the Middle Jurassic-to-Early Cretaceous rift structural style, with diapirism characterising hangingwall basins where autochthonous salt was thick and halite-rich, and salt-detached normal faulting occurring on the basin margins and on intra-basin structural highs where the salt was too thin and/or halite-poor to undergo diapirism. This variability is currently not captured by existing tectono-stratigraphic models largely based on observations from salt-free rifts and, we argue, mapping of suprasalt structural styles may provide insights into salt composition and thickness in areas where boreholes are lacking or seismic imaging is poor.

INTRODUCTION

The term 'salt' is typically used to describe halite-dominated rocks. However, 'salt' sequences may contain other evaporite rocks such as anhydrite or, its hydrated form, gypsum, and non-evaporite rocks such as carbonates and clastics (e.g. Warren, 2010, 2016; Hudec and Jackson, 2007; Jackson \& Hudec, 2017). These rocks have different mechanical properties and will accordingly show different styles of deformation when stressed (i.e. faulting of carbonates and clastics, flow of halite). These variations in lithology and mechanical properties, in addition to the bulk thickness of the salt and its overburden, are important to consider when examining the structural evolution of rifts forming in crust containing thick salt sequences. For example, the structural style and evolution of rifts containing relatively thick salt (e.g., Stewart et al., 1996, 1997; Pascoe et al., 1999; Withjack and Callaway, 2000; Richardson et al., 2005; Stewart 2007; Kane et al., 2010; Wilson et al., 2013; Rowan, 2014) differ significantly from salt-free rifts (e.g. Leeder and Gawthorpe, 1987; Prosser, 1993; Gawthorpe and Leeder, 2000). These differences arise because salt influences the degree and style of coupling between sub- and suprasalt deformation, and because activity on sub- and suprasalt faults can trigger salt flow and halokinesis (e.g. Vendeville \& Jackson, 1992; Jackson \& Vendeville, 1994). As a result, the physiography of and sediment dispersal patterns in, salt-influenced rifts may be more complex than in salt-free rifts, thus questioning the general applicability of widely used rift tectono-stratigraphic models (Gawthorpe and Leeder, 2000).

The Zechstein Supergroup is one of the world's best-known and largest salt giants, documenting 64 repeated flooding and evaporation of a continent-scale saline water body that covered much of NW Europe 65 during the Lopingian (i.e. late Permian) (e.g. Glennie et al., 2003; Bachmann et al., 2010; Jackson \& 66 Stewart, 2017; McKie, 2017; Soto et al., 2017). Notably, the Zechstein Supergroup occurs within the prerift 
succession to and likely influenced the development of, the Middle Jurassic-to-Early Cretaceous rift. Todate, most studies of Zechstein Supergroup compositional variations have focussed on the southern North Sea and the north-western margin of the North Permian Basin (Fig. 1). For example, Clark et al. (1998), using seismic reflection and very sparse borehole data from the north-western margin of the North Permian Basin, demonstrate the Zechstein Supergroup is characterised by a thick sequence of halite and anhydrite in the basin centre, and a relatively thin carbonate-clastic sequence at the basin margin (Figs 2 and 3). Based on the overall thickness and seismic expression of the Zechstein Supergroup, and the approximate percentage of halite, Clark et al. (1998) map four basin-scale depositional zones or 'DZs' (DZ1-4; see also Taylor, 1990). DZ1, which contains $<10 \%$ halite, occurs at the basin margin or on normal fault-bound, intra-basin structural highs (Fig. 3). DZ2 (10-50\% halite) and DZ3 (50-80\% halite) occur on basinwarddipping ramp-like areas, whereas DZ4 ( $>80 \%$ halite), which constitutes the majority of the fill of the North Permian Basin, occurs towards the basin centre (Fig. 3). It should be noted that, although elegant, the model of Clark et al. (1998) is supported by only sparse borehole data

Compared to the UK sector, almost nothing is known about basin-scale compositional variations in the Zechstein Supergroup in the Norwegian sector of the North Sea Basin (see Jackson \& Stewart, 2017). Jackson and Lewis (2016) use 3D seismic and reflection data from the Sele High Fault System, eastern Sele High, to document rapid across-fault variations in salt thickness and composition, demonstrating the footwall apex of this large-displacement fault system (>2 km) is capped by relatively thin $(58 \mathrm{~m})$, largely immobile carbonate and claystone, whereas relatively thick (>200 m) and mobile halite occurs in the adjacent hangingwall. The study of Jackson and Lewis (2016) covers only a relatively small area (c. 3600 $\mathrm{km}^{2}$ ) however, and to-date there has been no systematic regional study of basin-scale compositional variability in the Zechstein Supergroup. Establishing this is important for two key reasons. First, given that they appear directly related to syn-depositional basin structure, compositional variations may shed light on the Lopingian physiography of the Norwegian sector of the North Permian Basin. More specifically, they may reveal whether salt deposition occurred in a large unfaulted sag-like basin following an earlier period of rifting, or in an active rift. Second, and because of variability in the mechanical properties of evaporite and non-evaporite rocks, intra-Zechstein compositional variations may influence the structural style and evolution of the Middle Jurassic-to-Early Cretaceous rift, which, at least in it southern reaches, developed in the presence of salt.

We here use borehole data to map basin-scale $\left(c .30000 \mathrm{~km}^{2}\right)$ variations in Zechstein Supergroup composition on the north-eastern margin of the North Sea Basin. We also use long-offset, 2D seismic reflection data to examine variations in Zechstein Supergroup thickness and geometry, and to constrain the present sub- and suprasalt structure of the study area. By combining stratigraphic and structural data we are 
able to investigate the role that composition variations in the Zechstein Supergroup had on the syn-rift structural styles and evolution of the Middle Jurassic-to-Early Cretaceous rift system. We show that compositional variations in the Zechstein Supergroup are strongly controlled by syn-depositional basin relief; this relief may have been inherited from an earlier (i.e. presalt) tectonic event, or have formed during salt deposition (i.e. synsalt). Furthermore, variations in salt composition and thickness strongly influenced the Middle Jurassic-to-Early Cretaceous rift structural style; classic salt-tectonic, diapirism-dominated structural styles form in areas where the autochthonous salt was thick and halite-rich, whereas salt-detached normal faulting and only very minor diapirism occurs on the basin margins and on intra-basin structural highs where salt is thin and/or halite-poor. Based on our findings, we suggest current rift basin tectonostratigraphic models need modifying to take into account the presence of pre-rift salt.

\section{TECTONO-STRATIGRAPHIC FRAMEWORK}

The study area is located in the Norwegian sector of the northern North Sea, with particular focus on the South Viking Graben, Utsira High, Ling Depression and Egersund Basin (Fig. 1). Carboniferous-to-Early Permian transtension drove initial normal fault-related basin subsidence and led to the formation of the Egersund Basin, and the South Viking, Ling and Åsta grabens (Coward, 1995; Roberts et al., 1995; Glennie, 1998; Coward et al., 2003; Zanella and Coward, 2003). Following continental extension, Lopingian thermal subsidence resulted in formation of the pan-European, North Permian Basin, which was subsequently overprinted by the Middle Jurassic-to-Early Cretaceous rift-related basins listed above (Fig. 1A). The study area lay towards the northern and north-western margins of the North Permian Basin (Fig. 1). A relative sea-level rise in the earliest Lopingian established marine-to-marginal marine conditions in the North Permian Basin, and repeated cycles of basin flooding and desiccation drove deposition of a $>1 \mathrm{~km}$ thick, evaporite-dominated unit (Zechstein Supergroup, herein referred to as 'salt'; Figs 1 and 2). Previous studies suggest that that the Zechstein Supergroup was up to $1.5 \mathrm{~km}$ thick in the South Viking Graben and Egersund Basin, and indicate that carbonates and clastics at the basin margins pass basinwards into anhydrites and halites in the basin axes (Pegrum and Ljones 1984; Sørensen et al., 1992; Thomas and Coward 1996; Evans et al., 2003; Jackson et al. 2010; Jackson \& Lewis, 2016).

The abundance of salt structures (e.g. pillows, diapirs) and rapid, large-magnitude variations in the thickness of Triassic deposits confirms that post-depositional flow of Zechstein Supergroup salt occurred in the South Viking and Ling Depressions during the Triassic (Pegrum and Ljones, 1984; Sørensen et al., 1992; Erratt, 1993; Thomas and Coward, 1996, Jackson and Larsen, 2009; Kane et al., 2010). In contrast, the Åsta Graben, which likely contained thinner and/or less mobile evaporites, was less affected by salt 
movement and was instead dominated by rift-related extension and faulting. In the Early Jurassic,

134 impingement of a mantle plume at the base of the lithosphere led to the formation of the Mid-North Sea

135 Dome, which drove transient uplift of much of the southern Viking Graben, the Moray Firth, and the north

136 and north-east Central Graben. Because of this major tectonic event, Triassic and older stratigraphic units

137 were locally completely eroded and Early Jurassic strata are locally absent due to non-deposition or erosion.

138 During the Middle to Late Jurassic, a combination of the collapse of the Mid-North Sea Dome and

139 extensional faulting led to flooding of the North Sea Rift System (Cockings et al., 1992; Thomas and

140 Coward, 1996; Coward et al., 2003; Lyngsie et al., 2006).

Crustal extension during the Late Jurassic and Early Cretaceous reactivated many of the Permo-

143 Bounding Fault Zone that bounds the western margin of the South Viking Graben; the Sele High and

144 Stavanger fault systems that bound the Egersund Basin and Åsta Graben; Lewis et al., 2013; Jackson \&

145 Lewis, 2016). Basement-involved faulting and tilting during the Late Jurassic and Early Cretaceous also

146 drove salt flow and the growth of diapirs, extension of supra-salt strata, and formation of salt-detached

147 (supra-salt) normal fault arrays (Thomas and Coward, 1996; Jackson and Larsen, 2009; Lewis et al., 2013;

148 Tvedt et al., 2013; Jackson and Lewis, 2016). Although some of the larger structures continued to be active,

149 many of the rift-related normal faults became inactive during the Late Cretaceous in response to declining

150 rates of crustal extension (Knott et al., 1993; Thomas and Coward, 1996; Knott, 2001; Fraser et al., 2003).

151 During the Late Cretaceous to Cenozoic, the Northern North Sea subsided due to cooling of the crust

152 following Late Jurassic-to-Early Cretaceous rifting; subsidence was, however, punctuated by a period of

153 inversion that resulted in squeezing and amplification of salt diapirs and local reverse reactivation of normal

154 faults (e.g. Biddle and Rudolph, 1988; Cartwright, 1989; Sørensen et al., 1992; Fraser et al 2003; Jackson

155 et al., 2013).

156

\section{DATASET AND METHODS}

158

This study integrates wireline log data from 22 wells and 2D seismic reflection profiles covering Norwegian North Sea exploration blocks 8-10, 16-18 and 25 (Fig. 1). The seismic profiles are spaced every c. $5 \mathrm{~km}$ in

161 the south-east and c. $10 \mathrm{~km}$ in the north-west of the study area. The seismic data are time-migrated and are

162 presented in two-way time (TWT). The record length is 9 sec TWT, which is sufficient for imaging subsalt

163 units across much of the basin. The heights of halite-rich salt structures (e.g. diapirs) are calculated using 164 an interval velocity for salt of $4500 \mathrm{~m} / \mathrm{s}^{-1}$. All profiles are displayed with 'normal' polarity (i.e. an increase 165 in acoustic impedance with depth is represented by peak or black reflection, whereas a decrease in acoustic 
impedance with depth is represented by trough or red reflection; see Brown, 2004). Twenty-two exploration wells, which fully or partially penetrate the Zechstein Supergroup, allow a petrophysical characterisation of the key lithologies within the Zechstein Supergroup and regional and local mapping of these units (Fig. 1 and Table 1). Key lithostratigraphic or chronostratigraphic surfaces were identified in wells and tied to the seismic data. Five regionally correlatable seismic horizons were interpreted: (i) top Rotliegend Group (top middle Permian); (ii) top Zechstein Supergroup (top Permian); (iii) top Hegre Group (approximate top Triassic); (iv) top Viking/Boknfjord Group (top Jurassic); and (v) top Shetland/Chalk Group (top Cretaceous) (Fig. 2). Based on the distribution of seismic and well data we define two main study areas; a northern area that focuses on the South Viking Graben, Utsira High and Sleipner Terrace, and a southern area focused on the Ling Depression, Sele High and Egersund Basin (Fig. 1).

To identify evaporite and non-evaporite lithologies in the Zechstein Supergroup we combined observations from wireline petrophysical logs and cuttings data (from well reports and composite logs) from 10 of the 22 wells. Cuttings data were used to identify the principal Zechstein Supergroup lithologies, whose petrophysical expression was then constrained by extracting corresponding log values at 1,10 and $20 \mathrm{~m}$ intervals, depending on unit thickness (i.e. 0-500 m, 500-1000 $\mathrm{m}$ and >1000 $\mathrm{m}$ thick respectively). A total of 1307 points were extracted and used to create cross-plots (i.e. sonic velocity vs. density; GR vs. sonic velocity); these cross-plots defined petrophysical ranges for each lithology that then allowed us to interpret lithology variations from wireline logs in wells (or sections of wells) lacking cuttings data (see next section). We then defined seven lithologies or 'petrophysical facies': (i) anhydrite; (ii) halite; (iii) carnallite (i.e. a mineral consisting of a hydrated potassium or magnesium chloride); (iv) 'carbonate' (dolomite and limestone); (v) shale-claystone; (vi) siltstone, and (vii) sandstone (Fig. 4 and Table 2).

Regional stratigraphic correlations based on well data and tied to regional seismic reflection profiles were then constructed to examine the lateral variation in Zechstein Supergroup lithology and thickness. These combined well $\mathrm{log} /$ seismic stratigraphic correlations allowed the structural context of individual wells to be identified (i.e. whether a well is located in the basin centre, at the basin margin, on an intra-basin structural high, in a major salt structure, etc; Table 1). However, due to a lack of biostratigraphic data and because of substantial post-depositional salt flow, it is not possible to correlate individual, metre- to decametre-scale, evaporite or non-evaporite stratigraphic packages within the Zechstein Supergroup. We acknowledge that post-depositional salt flow likely resulted in some tectonic modification of the primary depositional stratigraphy due to preferential expulsion of more mobile lithologies (e.g. halite and carnallite; "tectonic purification by movement"; sensu Kupfer, 1968; see also Hudec and Jackson, 2007; Cartwright et al., 2012; Jackson et al., 2014a). For example, a well may be halitepoor simply because halite flowed into and inflated flanking diapirs; in this case, this well will be 
erroneously assigned to DZ1 or 2 and not DZ3 or 4. However, we argue our seismic reflection and well data provide an acceptable record of the primary lithology distribution within the Zechstein Supergroup; more specifically, areas dominated by thick, halite-dominated sequences are characterised by diapirs, whereas those characterised by thin, halite-poor sequences lack such structures. Furthermore, to help us assign individual wells to specific depositional zones, we use seismic reflection data to provide structural context to each well; i.e. does it lie within an area lacking any evidence for salt movement (in which case it likely lies within DZ1 or 2), or does it penetrate an area of pronounced diapirism, and if so, is it within the core of a diapir or in a flanking area of thin salt (in which case it likely lies within DZ3 or 4) (see Table $1)$.

\section{PETROPHYSICAL EXPRESSION OF THE ZECHSTEIN SUPERGROUP}

Density (RHOB)-sonic velocity (DT) cross-plots were used to differentiate between halite and anhydrite; halite has relatively low density $\left(1.9-2.3 \mathrm{~g} / \mathrm{cm}^{3}\right)$ and moderate velocity $(65-73 \mu \mathrm{s} / \mathrm{ft})$, whereas anhydrite has relatively high density (typically $2.7-3.1 \mathrm{~g} / \mathrm{cm}^{3}$ ) and very high velocity (typically $49-58 \mu \mathrm{s} / \mathrm{ft}$ ) (Fig. 4; Table 2). Overlap of the anhydrite and carbonate fields on RHOB-DT cross-plots suggests the anhydrite may be impure, although the former is identified based on its much lower velocity $(<55 \mu \mathrm{s} / \mathrm{ft})$ and slightly higher density (>2.8 g/cm³) (Fig. 4). Carbonate and clastic (especially claystone) rocks overlap in terms of these density (2.3-2.9 g/ $\left.\mathrm{cm}^{3}\right)$, velocity (48-90 $\mu \mathrm{s} / \mathrm{ft}$ ) and radioactivity (10-250 API), although siltstone/sandstone typically has overall lower velocity (typically $>75 \mu \mathrm{s} / \mathrm{ft}$ ) and radioactivity (35-60 API). It is therefore impossible to discriminate between carbonate and claystone in wells (or sections of wells) lacking cuttings (Figs 4 and 5; see also Table 2). More generally, the highly variable and overlapping petrophysical characteristics of the carbonate and clastic lithologies suggest they were incorrectly identified in cuttings data, or that they are impure, containing a mixture of, for example, anhydrite and claystone (i.e. a 'dirty anhydrite') or sandstone and carbonate (i.e. 'sandy carbonate'). Carnallite is relatively rare in the Zechstein Supergroup and thus infrequently sampled in cuttings. As a result, this lithology is identified in wells based on higher radioactivity (0-50 API), lower density $\left(2-2.2 \mathrm{~g} / \mathrm{m}^{3}\right)$, and higher velocity $(58-70 \mu \mathrm{s} / \mathrm{ft})$ values than other evaporite lithologies (i.e. halite and anhydrite; Table 2). Despite the limitations of our wireline logbased analysis, we feel it provides a good first-order assessment of lithology variations in the Zechstein Supergroup. More specifically, these data allow us to discriminate between evaporite and non-evaporite lithologies; this is a crucial distinction, given the amount of evaporite ultimately governs the mobility of the Zechstein Supergroup, and the structural style and evolution of the rift. 
A regional two-way time (TWT) thickness (isochron) map shows that the Zechstein Supergroup is typically c. $200 \mathrm{~ms}($ c. $450 \mathrm{~m})$ thick, but is up to $1000 \mathrm{~ms}($ c. $2250 \mathrm{~m})$ thick in diapirs located in the axes of the major fault-bound depocentres (e.g. the Ling Depression, where diapirs are penetrated by 16/11-1S and 16/8-2; Fig. 6; see also seismic profiles in Figs. 7-10). Towards the eastern margin of the South Viking Graben the Zechstein Supergroup is relatively thin ( $<100 \mathrm{~ms}$ TWT; c. $225 \mathrm{~m})$ and salt structures are sparse. The Zechstein Supergroup is also thin on intra-basin structural highs such as Sele High $(<60 \mathrm{~m} ; 17 / 12-2)$ and Sleipner Terrace (<100 m; 16/1-2). Seismic data thus suggest a first-order positive relationship between the present thickness and mobility of the Zechstein Supergroup (e.g. thick Zechstein Supergroup is mobile; thin Zechstein Supergroup is immobile; Jackson \& Lewis, 2016). Furthermore, basement-involved normal faults appear to exert a primary control on the Zechstein Supergroup thickness, with the unit being thinnest on basin margin or intra-basin, fault-bound structural highs (e.g. Sele High and flanks of Utsira High), and thickest in deep basins such as the Ling Depression (Fig. 6). Below we describe the thickness and composition of the Zechstein Supergroup in three sub-areas, and assign individual wells to specific saltrelated depositional zones. We then relate these salt-related depositional zones to the styles of salt-diapirism and rift-related deformation.

\section{Sub-area 1: South Viking Graben, Sleipner Terrace and Utsira High}

The correlation panel in Figure 7 illustrates variations in thickness and lithology of the Zechstein Supergroup between relatively deep depocentres such as the South Viking and Ling Depressions, and relatively shallow, basin margin locations such as the western margin of the Utsira High and the Sleipner Terrace. Four wells $(15 / 5-3,16 / 4-1,15 / 9-9 \& 15 / 12-3)$ on this panel penetrate the entire Zechstein Supergroup succession, whereas 15/12-2 only penetrates its upper $37 \mathrm{~m}$. Wells located in the axis of the South Viking Graben (15/5-3) and Ling Depression (15/12-3) penetrate diapirs and indicate that the Zechstein Supergroup, which in well 15/5-3 is up to $1046 \mathrm{~m}$ thick, is dominated by halite (93\% of the penetrated thickness) with relatively thin $(<30 \mathrm{~m})$ intervals of anhydrite and more rarely, carnallite. Using the scheme of Clark et al. (1998), 15/5-3 lies in DZ4. In the axis of the Ling Depression the Zechstein

262 Supergroup is $1203 \mathrm{~m}$ thick, with the upper $743 \mathrm{~m}$ being halite-dominated and containing thin $(<5 \mathrm{~m})$

263 carnallite layers (15/12-3; Fig. 7A). The lower $260 \mathrm{~m}$ of the succession is claystone-dominated, with 264 relatively thin $(<30 \mathrm{~m})$ anhydrite and halite intervals. Overall, $15 / 12-3$ comprises $>70 \%$ halite and it 
therefore lies within DZ3. Seismic data indicate that, in these deep basin locations, where the Zechstein Supergroup is relatively thick and halite-dominated (i.e. DZ3-4), large diapirs occur (Figs 7B). Thinning and onlap of the Triassic succession across these salt structures suggests salt flow occurred during the Triassic; a later period of flow during the Middle to early Late Jurassic is also locally indicated by thinning and onlap of the corresponding interval across some of the salt-cored structures (Fig. 7). 15/12-2, despite being anhydrite-dominated, is assigned to DZ3, given it penetrates the only the crest of a moderate-relief (c. $500 \mathrm{~ms}$ TWT; c. $1125 \mathrm{~m}$ ) diapir, the presence of which indicates the Zechstein Supergroup is relatively thick and mobile in this location (Fig. 7). We infer the anhydrite represents part of the diapir caprock (e.g. Warren, 2016).

In contrast to the deep basin wells, 16/4-1 and 15/9-9, which are located on present-day structural highs defining the basin margins, contain a relatively thin, halite-poor Zechstein Supergroup (Fig. 7). In 16/4-1, located on the western margin of the Utsira High, the Zechstein Supergroup is dominated by clastic lithologies (siltstone and sandstone) with only minor anhydrite and carbonate. Likewise, 15/9-9, located on the Sleipner Terrace, is largely composed of anhydrite with minor carbonate; halite is lacking. The halitepoor nature of these wells places both of these wells and the domains they represent within DZ1. Seismic data indicate that at the basin margins, where the Zechstein Supergroup is relatively thin and halite-poor (i.e. DZ1), salt structures are very rare, with very little relief being developed at top salt (Fig. 7B).

A correlation panel along the western flank of the Utsira High further illustrates the variations in thickness and lithology occurring in the Zechstein Supergroup at the basin margin (Fig. 8). Four wells completely penetrate a relatively thin $(<150 \mathrm{~m})$ Zechstein Supergroup succession, but only 16/1-2 and 16/72 occur close to seismic reflection profiles (Fig. 8). All of the wells lack halite and are dominated by nonevaporitic lithologies such as carbonate, fine-grained clastics and anhydrite. In the most northern well, evaporite facies are completely absent and the Zechstein Supergroup is composed only of claystone and carbonate (25/10-4R). Well 25/10-2R, which is located on the western flank of the Utsira High, is carbonate-rich (50\%), particularly towards its base, but it also contains anhydrite with a thin shale-claystone layer at the top of the Zechstein Supergroup. Well 16/1-2, is also carbonate-dominated, although anhydrite occurs in the middle of the Zechstein Supergroup and claystone is found towards its top and base (Fig. 8). The upper and lower parts of the Zechstein Supergroup in well 16/7-2, located at the southern tip of the Utsira High, are carbonate-rich, although anhydrite and shale-claystone are prevalent in the middle part of the well. Based on their lack of halite, wells along the flanks of the Utsira High are representative of DZ1. As we observed for the south-western Utsira High and the Sleipner Terrace: (i) salt structures are absent on the basin margins where the Zechstein Supergroup is relatively thin and halite-poor (i.e. DZ1); and (ii) 
basement-involved faults locally cross-cut halite-poor Zechstein Supergroup, extending up into the Mesozoic succession (Fig. 8B). We discuss the significance of these two observations below.

\section{Sub-area 2: Ling Depression, Sele High and Åsta Graben}

Two broadly E-trending correlation panels illustrate the variations in Zechstein Supergroup thickness and lithology occurring between the present basin margins (i.e. Sleipner Terrace) and intra-basin highs (i.e. Sele High; Fig. 9), and the adjacent fault-bound depocentres (i.e. Ling and Åsta grabens; Fig. 10). Beginning with the most northerly of these two panels (Fig. 9), our data show that, on the Sleipner Terrace, the Zechstein Supergroup is 25-64 m thick and it is notable for its lack of halite. Instead, the Zechstein Supergroup is dominated by anhydrite $(74 \% ; 15 / 9-16)$ or claystone $(48 \% ; 16 / 7-3)$, with moderate amounts of carbonate (26-27\% in 15/9-16 and 16/7-3). The Zechstein Supergroup succession is thus compositionally similar to that encountered along the eastern flank of the South Viking Graben, on the margin of the Utsira High (cf. Fig. 8). Wells 16/8-2 and 16/9-1, which are located within the Ling Depression only $17 \mathrm{~km}$ to the east of 16/7-3, are separated from the Sleipner Terrace by a south-eastward dipping, NE-SW-striking normal fault that has $660 \mathrm{~ms}$ of throw at top Rotliegend Group level (Figs. 1 and 9B). In the hangingwall of the fault system, 16/8-2 penetrated a salt wall at least $1325 \mathrm{~m}$ thick and comprising $94 \%$ halite with minor amounts of anhydrite, carbonate and carnallite; the Zechstein Supergroup in this location can be included in DZ4. Well 16/9-1, which is also located on the western flank of the Sele High, only penetrated the upper $140 \mathrm{~m}$ of a c. $450 \mathrm{~m}$ thick Zechstein Supergroup succession and is dominated by anhydrite (63\%), although halite is present (35\%), together with a thin $(<10 \mathrm{~m}$ ) claystone cap (Fig. 9). Based exclusively on the lithologies encountered in its upper part, the Zechstein Supergroup in this well is assigned to DZ3. Seismic data indicate again that structural style is closely coupled to Zechstein Supergroup thickness and composition; on the basin margins, where the unit is thin and halite-poor (i.e. DZ1-2), no salt structures or only very low-relief pillows occur, with normal faults cross-cutting the salt and extending from subsalt into suprasalt strata (i.e. Sele High and Sleipner Terrace; Fig. 9B). In contrast, in the basin centre, where the unit is thick and halite-rich (i.e. DZ3-4), diapirs are common (i.e. Ling Depression; Fig. 9B). Supra-salt, salt-detached normal faults, which extend up into Tertiary strata, are also developed in basin centre locations (Fig. 9B).

The southerly of the two panels further highlights the lateral lithology and thickness variations occurring in the Zechstein Supergroup between intra-basin, fault-bound highs and adjacent depocentres (Fig. 10). 16/10-1, 16/11-1S and 17/11-1 are located within the Ling Depression and, although none of these wells penetrate the entire thickness of the Zechstein Supergroup, through the use seismic data it is 
possible to constrain the approximate thickness of the Zechstein Supergroup at each well location by projecting the wells onto the seismic data. This exercise suggests $16 / 10-1$ penetrates the upper $35 \mathrm{~m}$ of a salt wall that is c. $315 \mathrm{~m}$ thick (Fig. 10A). Wireline-log data suggest the Zechstein Supergroup is dominated by halite $(66 \%)$, with anhydrite, claystone and rare carnallite occurring in the upper few tens of metres (DZ3). 16/11-1S also penetrates a salt wall, with seismic data suggesting the Zechstein Supergroup in this location is c. $820 \mathrm{~m}$ thick (Fig. 10). The upper $794 \mathrm{~m}$ of the Zechstein Supergroup is penetrated in this well, with wireline-log data indicating it is composed almost entirely of halite (99\%) with minor amounts of anhydrite and carbonate in the upper $38 \mathrm{~m}$ (DZ4). Well 17/11-1, which is located in the Ling Depression, penetrates the Zechstein Supergroup in an area that appears to have undergone relatively limited amounts of post-depositional salt flow. The well penetrates a $755 \mathrm{~m}$ thick succession of the Zechstein Supergroup, with seismic data suggesting a further c. $15 \mathrm{~m}$ of Zechstein Supergroup occurs beneath the base of the well. In this location the Zechstein Supergroup is dominated by halite (78\%), with carnallite and carbonate-rich intervals occurring in the lower $50 \mathrm{~m}$, and anhydrite and carbonate-rich intervals occurring in the upper 20 m (Fig. 10). Decimetre-thick carbonate intervals also occur in the upper third of the unit. Based on these bulk lithological variations, the Zechstein Supergroup in this location is assigned to DZ3. Well 17/12-2, which is located $22 \mathrm{~km}$ updip to the east of 17/11-1, on the eastern margin of the Sele High, in the immediate footwall of the Sele High Fault System, fully penetrates a thin (49 m), carbonate-dominated (84\%) Zechstein Supergroup (DZ1). Well 17/12-1R, which is located $15 \mathrm{~km}$ to the east of 17/12-2 and in the hangingwall of the Sele High Fault System, penetrates the upper $100 \mathrm{~m}$ of a $450 \mathrm{~ms}$ TWT (c. $1013 \mathrm{~m}$ ) thick salt pillow (Fig. 10B; see also Jackson \& Lewis, 2015). The Zechstein Supergroup in the well is composed predominantly of halite (69\%), although the upper $27 \mathrm{~m}$ is dominated by anhydrite and claystone; by assuming the salt pillow below the termination of the well is halite-dominated, we tentatively place 17/121R in DZ4 (Fig. 10). We interpret the $27 \mathrm{~m}$ thick anhydrite and claystone-rich unit capping the pillow represents caprock (e.g. Warren, 2016).

When considering the salt- and rift-related structural styles we note that large Triassic-to-Jurassic minibasins are flanked by diapirs in the basin centre and on the lower flanks of intra-basin highs where the Zechstein Supergroup is thick and halite-rich (i.e. DZ3-4) (i.e. Ling Depression; Fig. 10B). On crests of intra-basin fault-bound highs, where the unit is thin and halite-poor (i.e. DZ1-2), no large salt structures occur, although small rollers are present in the footwalls of salt-detached faults (i.e. Sele High; Fig. 10B). However, downdip of structural culminations such as the Sele High, in areas ascribed to DZ2 and 3 (i.e. $10-80 \%$ halite), seismic data image a range of salt-related structures including diapirs, minibasins and rafts (Figs 11, 12, and 13). 
A correlation panel (Fig. 14) covering the south-eastern part of the Egersund Basin and the north-eastern edge of the Lista Fault Blocks illustrates lithological variations in the Zechstein Supergroup immediately adjacent to the Stavanger Platform. Based on the lithology of the Zechstein Supergroup sampled by wells in this location, the Zechstein Supergroup has been assigned to DZ1 (i.e. 10/7-1 and 10/5-1) and DZ3 (i.e. 10/8-1). For example, 10/7-1, located on the eastern edge of the Egersund Basin, appears to sample the upper $45 \mathrm{~m}$ of a diapir flank. The well lacks halite and is composed solely of non-evaporitic lithologies; the lower part of the well is clastic-dominated whereas the upper part of the well is dominated by carbonate (Fig. 4). Again, because 10/7-1 only penetrates the upper part of the salt, assigning a depositional zone is not straightforward, with the well penetrating the upper part of a large (1500 ms TWT; $667 \mathrm{~m}$ tall) diapir developed above a horst (Fig. 14). As such, we infer that well samples caprock, and potentially straddles the boundary between an area of thick, mobile salt to the SW in the Egersund Basin and thinner, slightly less mobile salt to the NE on the Lista Fault Blocks. We suggest the diapir was thus either fed by mobile salt expelled from the hangingwall during rifting (cf. Dooley et al., 2005; Burliga et al., 2012), or that the whole area, including the horst, was characterised by relatively thin but still mobile salt, with the sub-salt, basement-involved faults forming later and offsetting the base of the salt. Well 10/8-1, which is situated on the Lista Fault Blocks, penetrates the upper part of a salt pillow and indicates the Zechstein Supergroup is composed of anhydrite (12\%) and claystone (22\%) that overlie a halite-rich (66\%) succession (DZ3). Finally, in 10/5-1, which is located near the boundary between the Lista Fault Blocks and the Stavanger Platform (Fig. 1), and which appears to penetrate the lower flank of moderately large (500 ms TWT) diapir, the Zechstein Supergroup is $217 \mathrm{~m}$ thick and lacks halite. Instead, a $138 \mathrm{~m}$ thick, carbonate-rich succession overlies an anhydrite and marl-rich unit that is underlain by a clastic-rich unit defining the base of the Zechstein Supergroup (DZ1). Given the lack of halite, the Zechstein Supergroup should not be mobile in this location, suggesting: (i) the well, which is projected $1175 \mathrm{~m}$ onto the seismic profile in Fig. 14, actually lies on a structural high that lies away from this profile (see Fig. 1); or (ii) the well does indeed intersect a diapir, but that it penetrates an area where halite has been preferentially expelled into the flanking diapir (e.g. Kupfer, 1968; Hudec and Jackson, 2007; Cartwright et al., 2012; Jackson et al., 2014a). 
Well and 2D seismic reflection data have allowed us to define the present thickness and lithological variations in the Zechstein Supergroup along the northern margin of the North Permian Basin, offshore SW Norway. These data indicate that the Zechstein Supergroup is relatively thin $(<200 \mathrm{~m})$ and halite-poor (i.e. DZ1 and 2) at the basin margins and on normal-fault bound, intra-basin structural highs (e.g. Sele High). In these locations the unit is dominated by anhydrite and non-evaporitic lithologies such as claystone, carbonate and siltstone. In contrast, the Zechstein Supergroup is relatively thick (>200 m) and halite-rich (i.e. DZ3 and 4) in the relatively deep, normal fault-bound basins (e.g. Ling Depression, Egersund Basin and the axis of the South Viking Graben). In these locations, anhydrite and claystone only occur as part of caprock sequence. Changes in lithology across basement-involved normal faults can be relatively abrupt (e.g. between the Sleipner Terrace and the Ling Depression; Fig. 9 and between the Sele High and the Egersund Basin; Figs 7 and 15), or gradational (e.g. between the South Viking Graben and Utsira High; Fig. 7). Moderately halite-rich parts of the Zechstein Supergroup (DZ2 and 3) occur in transitional areas, such as fault-bound, basin-margin terraces or on largely unfaulted, gently basinward-dipping ramps (e.g. western margin of the Utsira High).

Similar relationships between thickness, composition, and structural position have been described from the UK sector of the North Sea (Fig. 3; Clark et al., 1998; Stewart, 2007; see also Jackson and Lewis,

413 Norway to produce what we believe is the first, almost fully northern North Sea-wide map of the Zechstein 414 Supergroup distribution and lithology (Fig. 15). Even though the relationship between Zechstein 415 Supergroup thickness and composition, and structural position is strong, it is not clear if the thickness, and 416 potentially, the primary lithological variability of the unit has been strongly modified by post-depositional 417 flow; in this case, unit thickness and composition may not, therefore, reflect or be used to infer the syn418 depositional basin physiography. For example, does thinning of the Zechstein Supergroup onto the 419 basement margins reflect a primary depositional pinchout or merely an erosional boundary related to post420 depositional erosion/dissolution? Related to this, does the thin/halite-poor nature of the Zechstein 421 Supergroup at the basin margins and on intra-basin structural highs, and the thick/halite-rich nature of the 422 unit of the unit in the basin centre, reflect a eustatic control on deposition (see Tucker, 1991), or simply the 423 impact of post-depositional tectonics and erosion on preservation and composition? We propose that one 424 or a combination of the four following end-member models may account for the thickness and lithology 425 variations observed in the Zechstein Supergroup (Fig. 16; see also Jackson and Lewis, 2013).

427 (i) Model 1 (Fig. 16a). The Zechstein Supergroup was deposited within a largely unstructured, bowl-shaped 428 basin and was halite-rich across the entire basin, including the basin margins and the future positions of 
intra-basin structural highs. Post-depositional uplift associated with subsequent Triassic and/or Middle Jurassic-to-Early Cretaceous rifting resulted in erosion and dissolution of the halite components of the Zechstein Supergroup, and the relative enrichment in non-halite lithologies at the basin margins and on intra-basin structural highs. Erosion, dissolution and relative enrichment of the Zechstein Supergroup in anhydrite may also have occurred in response to exposure of the Zechstein Supergroup at the flexural rather than fault-bound basin margins of the North Permian Basin during Triassic exposure.

(ii) Model 2 (Fig. 16b). The Zechstein Supergroup was deposited in a largely unstructured, bowl-shaped basin and was characterised by syn-depositional changes in thickness and lithology, with halite- and carnallite-poor successions at the basin margin passing basinwards into halite-rich successions in the basin centre (e.g. Clark et al., 1998; Stewart, 2007). This transition could have been gradual if the margin was ramp-like, and not defined by major carbonate buildup-related relief at the basin margin, or more abrupt if such relief was present (Tucker, 1991). Irrespective of how abruptly halite-poor intervals passed into haliterich intervals, post-depositional flow of the Zechstein Supergroup was strongly partitioned, with mobile halite being preferentially expelled from the source layer on the basin margin into flanking salt structures, resulting in local enrichment of non-halite lithologies in areas where the Zechstein Supergroup is thin. This model applies not only to areas where salt is thin due to the subsalt basin structure, but also due to welding due to post-depositional flow (Kupfer, 1968; Wagner and Jackson, 2011; Jackson et al., 2014).

(iii) Model 3 (Fig. 16c). The Zechstein Supergroup was deposited in a bathymetrically complex basin, the physiography of which was inherited from the Early Permian rift event. Flooding of the basin by the Zechstein Sea during the Lopingian resulted in halite deposition in high accommodation areas (e.g. underfilled basin centre) during sea-level lowstand and carbonate/anhydrite deposition in low accommodation areas (e.g. overfilled basin margin) during sea-level highstand (cf. Tucker, 1991). In this model, subaerial exposure of the Zechstein Supergroup at the basin margin or on intra-basin structural highs during the Triassic or Middle Jurassic-to-Early Cretaceous may have slightly modified the primary lithology and thickness variations in the unit.

(iv) Model 4 (see also Fig. 16c). The Zechstein Supergroup was deposited in a bathymetrically complex basin, the physiography of which was controlled by syn-depositional (i.e. Lopingian) rift-related normal faulting. In a similar manner to Model 3, Model 4 envisages that halite was deposited in highaccommodation areas during sea-level lowstand and carbonate/anhydrite deposition occurred in lowaccommodation areas at the basin margin during sea-level highstands (cf. Tucker, 1991). In this model, 
variations in the thickness and lithology of the Zechstein Supergroup were simply augmented by syndepositional faulting (not shown in Fig. 16c).

Although post-depositional erosion and dissolution (Model 1) undoubtedly impacted on the present thickness and lithology variations in the Zechstein Supergroup, we think it was unlikely to be the dominant control because many of the basin-centre successions contain almost no carbonate and, even when relatively thick salt is almost fully penetrated, relatively little anhydrite (e.g. 15/5-3; Fig. 7; 16/8-2; Fig. 9). This suggests that the successions encountered at the basin margins or on intra-basin structural highs cannot simply represent anhydrite- or carbonate-enriched versions of the basin-centre successions. We also discount preferential flow of halite as being the dominant control on the lithological variations in the Zechstein Supergroup because the thin successions encountered on the basin margin and intra-basin structural highs are not flanked by large salt structures (e.g. 15/9-9 and 16/4-1; Figs 7 and 9). Although Jackson and Lewis (2013) provide evidence for Early Permian rifting and faulting along at least the northern margin of the Egersund Basin, and despite dramatic changes in thickness and lithology occurring in the Zechstein Supergroup across basement-involved normal faults, we have no independent evidence for a regional phase of Lopingian extension, thus making it difficult to discriminate between Models 3 and 4 .

\section{Mechano-stratigraphic controls on structural style development in salt-influenced rift basins}

Salt is weaker than most other lithologies at significant (>500 m) burial depths, and flows like a fluid over geological timescales (e.g. Hudec and Jackson, 2007; Jackson and Hudec, 2017). As a result of these rheological properties, salt can strongly modify the structural style of rift basins. For example, salt can impede the vertical (and lateral) propagation of faults, and thus degree of sub- and supra-salt kinematic coupling (e.g. Stewart et al., 1996, 1997; Clark et al., 1998; Marsh et al., 2009; Duffy et al., 2013; Lewis et al., 2013; Wilson et al., 2013; Jackson \& Lewis, 2016; Ge et al., 2017). Furthermore, activity on basementrestricted, thick-skinned and supra-salt faults can trigger halokinesis by, for example, tilting the salt and triggering thin-skinned, gravity-driven deformation and causing reactive diapirism (e.g. Vendeville and Jackson, 1992). As a result, the structural style of salt-influenced rifts is markedly different to rifts that lack salt in their pre-rift mechano-stratigraphic template.

Here we have shown that spatial variations in the thickness and lithology of the evaporite-bearing Zechstein Supergroup control the structural styles that develop during Middle Jurassic-to-Early Cretaceous rifting (see also Lewis et al., 2013; Jackson and Lewis, 2016). Diapirism is common in hangingwall basins, where autochthonous salt was thick and halite-rich (e.g. DZs 3 and 4 of Clark et al., 1998). In contrast, at 


\section{Comparison to other saline giants}

513 Very few studies have documented the lithological variations occurring in 'salt giants' (sensu Hsü, 1972);

514 this may reflect a lack of borehole data with which to directly constrain such variations, or a lack of detailed

515 study on the evaporite-dominated stratigraphic interval in those particular basins. Where borehole data are 516 available, they indicate that lithology variations are strongly linked to the pre- or syn-depositional 517 physiography of the salt basin. For example, the middle Carboniferous-to-Permian, Paradox Basin, Utah, 518 USA is a large $(265 \mathrm{~km}$ by $190 \mathrm{~km})$, asymmetric, foreland basin that formed during the ancestral Rocky 519 Mountain orogenic event. Thrust sheet loading and long-wavelength crustal flexure led to the formation of 520 a gently north-eastwards dipping homocline, onto which a thick, evaporite-bearing sequence was deposited 521 (Paradox Formation; e.g. Barbeau, 2003; Trudgill et al., 2004; Matthews et al., 2007; Trudgill, 2011). 522 Because of the relatively simple basin geometry, somewhat predictable lithological and structural style 523 variations occur. In the basin centre the Paradox Formation is halite-rich, although potash, anhydrite and 524 organic-rich black claystone also occur. Together, these units are arranged into 29 evaporite-shale cycles 525 documenting periodic flooding and desiccation of the basin (Baars, 1983). In contrast, towards the basin 526 margins, the percentage of halite in the Paradox Formation decreases and the succession becomes 527 dominated by carbonates. Seismic reflection data indicate that the style of salt structures in the Paradox 
Basin reflect this lateral variation in lithology and inferred rheology of the 'salt'. For example, large salt diapirs characterise the halite-rich, basin centre locations, whereas the basin margin is relatively undeformed. A similar overall relationship between basin morphology, lithology variations, and structural style are observed in the Santos Basin, offshore Brazil (e.g. De Freitas, 2006; Moreira et al., 2007; Gamboa et al., 2008) and in the Mid-Polish Trough, Poland (e.g. Krzywiec, 2012).

Our study from the Norwegian sector of the North Sea Basin indicates that lithology and structural style variations are more complex in salt basins characterised by rapid changes in syn-depositional basin relief and eustatic sea-level variations. More specifically, the length-scales of lithology and thus structural style change are much shorter $(<1 \mathrm{~km})$ in rift basins (e.g. the Northern North Sea) where normal faults are present, in contrast to homoclinal ramp-like relief characterising the distal margins of foreland basins; in the latter, lithology and structural; style changes are more gradual, occurring over several tens of kilometres. We argue that the lack of salt structures on intra-basin structural highs does not simply reflect postdepositional uplift and erosion, but may instead indicate areas where salt tectonics never occurred due to the evaporite-bearing sequence lacking low-viscosity, mobile lithologies (e.g. halite, potash salt). Salt basin morphology is thus a key control on lithology distribution in salt giants, and the resulting spatial variations in the mechanical-stratigraphic of the pre-rift template may directly govern structural styles during subsequent phases of crustal extension (e.g. Stewart et al., 1996, 1997; Clark et al., 1998; Marsh et al., 2009; Duffy et al., 2013; Lewis et al., 2013; Wilson et al., 2013; Jackson \& Lewis, 2016; Ge et al., 2017).

\section{CONCLUSIONS}

We used 2D seismic reflection and well data to map basin-scale variations in the thickness and composition of the evaporite-dominated Zechstein Supergroup (Lopingian) in the Norwegian sector of the northern North Sea. We showed that the Zechstein Supergroup is dominated by halite, anhydrite and carbonate, with relatively minor amounts of claystone, sandstone and potassium salts (carnallite). Based on the proportion of halite, we identified and mapped four intrasalt depositional zones (DZs; sensu Clark et al., 1998), showing that the Zechstein Supergroup is relatively thin $(<200 \mathrm{~m})$, halite-poor (i.e. DZ1 and 2), and relatively enriched in anhydrite and non-evaporitic lithologies (claystone, carbonate and siltstonesandstone) at the basin margins and on normal-fault bound, intra-basin structural highs. In contrast, the Zechstein Supergroup is relatively thick (>200 m) and halite-rich (i.e. DZ3 and 4) in the relatively deep, normal fault-bound basins, and in these locations, anhydrite and claystone are rare, forming part of caprock sequences developed at the crests of salt diapirs and pillows. Transitions between these zones are either abrupt, occurring across large, basement-involved normal faults, or more gradational, occurring along 
largely unfaulted, gently-dipping ramps. Similar relationships between evaporite thickness and composition, and structural position (i.e. structural high vs. basin) are observed in the UK sector of the northern North Sea and in other ancient salt giants. It is presently unclear if the variability observed in the northern North Sea reflects variations in syn-depositional relief related to flooding of an underfilled presalt (Early Permian) rift or syn-depositional (Lopingian) rift-related faulting. Irrespective of the underlying controls, variations in salt composition and thickness clearly influenced Triassic depositional patterns via minibasin formation, and the Middle Jurassic-to-Early Cretaceous rift structural style, with diapirism characterising hangingwall basins where autochthonous salt was thick and halite-rich, and salt-detached normal faulting occurring on the basin margins and on intra-basin structural highs where the salt was too thin and/or halite-poor to undergo diapirism. Furthermore, the thickness and composition of the Zechstein Supergroup impact the degree of sub- and supra-salt kinematic coupling, with these structural levels being coupled where the unit is thin and halite-poor, and poorly coupled where it is thick and halite-rich. This variability is currently not captured by existing tectono-stratigraphic models largely based on observations from salt-free rifts. We suggest mapping of suprasalt structural styles (e.g. diapirs, salt-detached normal faults), in addition to subsalt structural highs and low (e.g. halite-rich basins, halite-poor structural highs), may provide insights into salt composition and thickness in areas where boreholes are lacking or seismic imaging is poor.

\section{ACKNOWLEDGMENTS}

This research presented in this paper formed part of the Statoil-funded Salt-Influenced Rift Basins (SIRB) project, which was based at Imperial College, the University of Manchester and the University of Bergen. We would like to acknowledge the technical input of numerous people based in the Norwegian North Sea South Licenses Team (Stavanger) and in the Research Centre (Bergen). We would also like to acknowledge are also thanked for their contribution to elements of the work presented here.

\section{REFERENCES}

BAARS, D.L. \& STEVENSON, G.M. (1981) Tectonic evolution of the Paradox basin, Utah and Colorado. Mount.

BAARS, D.L. (1983) The Colorado Plateau, a geologic history. University of New Mexico Press. 
BACHMANN, G.H., GELUK, M.C., WARRINGTON, G., BECKER-ROMAN, A., BEUTLER, G., HAGDORN, H., HOUNSLOW, M.W., NITSCH, E., RÖHLING, H.-G., SIMON, T. \& SZULC, A. (2010) Triassic. In: Doornenbal, J.C. and Stevenson, A.G. (editors): Petroleum Geological Atlas of the Southern Permian Basin Area. EAGE Publications b.v. (Houten), 149-173.

BARBEAU, D.L. (2003) A flexural model for the Paradox Basin: implications for the tectonics of the Ancestral Rocky Mountains. Basin Research, 15, 97-15.

602

BARTHOLOMEW, I.D., PETERS, J.M. \& POWELL, C.M. (1993) Regional structural evolution of the North Sea: oblique-slip and reactivation of basement lineaments. In: Petroleum Geology of Northwest

BIDDLE, K.T. \& RUDOLPH, K.W. (1988) Early tertiary structural inversion in the Stord basin, Norwegian 610

BISHOP, D.J. (1996) Regional distribution and geometry of salt diapirs and supra-Zechstein Group faults Europe: Proceedings of the 4th Conference (Ed. by J.R. Parker), pp. 1109-1122. Geological Society, London.

BRANTHER, S.R.F. (2003) The East Brae field, blocks 16/03a, 16/03b, UK North Sea. In: United Kingdom Oil and Gas Fields, Commemorative Millennium Volume (Ed. by J. Gluyas \& H.M. Hichens), Geological Society, London, Memoir 20, 191-197.

BREHM, J.A. (2003) The North and Beinn fields, block 16/7a, UK North Sea. In: United Kingdom Oil and Gas Fields, Commemorative Millennium Volume (Ed. by J. Gluyas \& H.M. Hichens), Geological Society, London, Memoir 20, 199-209.

BROWN, A. (2004) Interpretation of three-dimensional seismic data. AAPG Memoir 42, SEG Investigations in Geophysics, $9.6^{\text {th }}$ edn.

BURLIGA, S., KOYI, H.A., CHEMIA, Z (2012) Analogue and numerical modelling of salt supply to a diapiric structure rising above an active basement fault. In: Salt Tedtonics, Sediment and Prospectivity. 
(Ed. by G.I. Alsop, S.G. Archer, A.J. Hartley, N.T. Grant, R. Hodgkinson), Geol. Soc. London Spec. Publ., 363, 395-408.

CARTWRIGHT, J.A. (1989) The kinematics of inversion in the Danish Central Graben. Geological Society, London, Special Publications, 44, 153-175.

632

CARTWRIGHT, J.A., STEWART, S. \& CLARK, J. (2001) Salt dissolution and salt-related deformation of the Forth Approaches Basin, UK North Sea. Mar. Petrol. Geol., 18, 757-778.

CARTWRIGHT, J.A., JACKSON, M.P.A, DOOLEY, T., AND HIGGINS, S., 2012, Strain partitioning in gravity-driven shortening of a thick, multilayered evaporite sequence, in Alsop, G.I., et al., eds., Salt 470 ,

CLARK, J.A., STEWART, S.A. \& CARTWRIGHT, J.A. (1998) Evolution of the NW margin of the North Permian Basin, UK North Sea. J. Geol. Soc. of London, 155, 663-676.

COCKINGS, J.H., KESSLER, L.G. II, MAZZA, T.A., \& RILEY, L.A. (1992) Bathonian to mid-Oxfordian Next Decade (Ed. by R.F.P. Hardman), Geol. Soc. London Spec. Publ., 67, 65-105.

COWARD, M.P. (1995) Structural and tectonic setting of the Permo-Triassic basins of Northwest Europe. 655 In: Permian and Triassic Rifting in Northwest Europe (Ed. by S.A.R. Boldy), 91, 7-39.

COWARD, M.P., DEWEY, J.F., HEMPTON, M. \& HOLROYD, J. (2003) Tectonic evolution. In: The Millennium Atlas: Petroleum Geology of the Central and Northern North Sea (Ed. by D. Evans, C. 659 
DAVIES, R., DONNELL, D., BENTHAM, P.N., GIBSON, J.P.C., CURRY, M.R., DUNAY, R.E. \& MAYNARD, J.R. (1999) The origina and genesis of major Jurassic unconformities within the triple junction area of the North Sea, UK. In: Petroleum Geology of Northwest Europe: Proceedings of the 5th conference (Ed. by A.J. Fleet \& S.A.R. Boldy), pp. 117-131. Geological Society, London.

DAVISON, I., ALSOP, I. \& BIRCH, P. (2000) Geometry and late-stage structural evolution of Central Graben salt diapirs, North Sea. Mar. Petrol. Geol., 17, 499-522.

DE FREITAS, R.T.J. (2006) Ciclos Deposicionais Evaporiticos Da Bacia De Santos: Una Analise Cicloestratigrafica a Partir De Dados De 2 Pocos E De Tracos De Sismica., Universidade Federal do Rio Grande do Sul, Brazil.

DOOLEY, T., MCCLAY, K.R., HEMPTON, M. AND SMIT, D., 2005, January. Salt tectonics above complex basement extensional fault systems: results from analogue modelling. In Geological Society, London, Petroleum Geology Conference series (Vol. 6, No. 1, pp. 1631-1648). Geological Society of London.

DUFFY, O.B., GAWTHORPE, R.L., DOCHERTY, M. \& BROCKLEHURST, S.H. (2013) Mobile evaporite controls on the structural style and evolution of rift basins. Basin Research, 25, 310-330.

ERRATT, D. (1993) Relationships between basement faulting, salt withdrawal and Late Jurassic rifting, UK Central North Sea. In: Petroleum Geology of Northwest Europe: Proceedings of the 4th Conference (Ed. by J. R. Parker), pp. 1211-1219. Geological Society, London.

ERRATT, D., THOMAS, G.M. \& WALL G.R.T. (1999) The evolution of the Central North Sea Rift. In: Petroleum Geology of Northwest Europe: Proceedings of the 5th conference (Ed by A.J. Fleet \& S.A.R. Boldy), pp. 63-82. Geological Society, London.

EVANS D., ARMOUR, A., BATHuRSt, P., GAMMAGE, J., SWAllOW, J., GRAHAM, C. \& STEWART, H. (2003) Millennium Atlas: Petroleum Geology of Central \& Northern North Sea. London, The Geological Society of London, 390p. 
FLETCHER, K.J. (2003a) The Central Brae field, blocks 16/07a, 16/07b, UK North Sea. In: United Kingdom Oil and Gas Fields, Commemorative Millennium Volume (Ed. by J. Gluyas \& H.M. Hichens), 20, 183-190. Geological Society of London.

FLETCHER, K.J. (2003b) The South Brae field, blocks 16/07a, 16/07b, UK North Sea. In: United Kingdom Oil and Gas Fields, Commemorative Millennium Volume (Ed. by J. Gluyas \& H.M. Hichens), 20, 211221. Geological Society of London.

FRASER, S.I., ROBINSON, A.M., JOHNSON, H.D., UNDERHILL, J.R., KADOLSKY, D.G.A., CONNELL, R., JOHANNESSEN, P. \& RAVNAS, R. (2003) Upper Jurassic. In: The Millennium Atlas: Petroleum Geology of the Central and Northern North Sea (Ed. by D. Evans, C. Graham, A. Armour \& P. Bathurst), pp. 157-189. The Geological Society of London, London.

GAMBÔA, L.A.P., MACHADO, M.A.P., SILVEIRA, D.P., DE FREITAS, J.T.R. \& DA SILVA, S.R.P. (2008) Evaporitos Estratificados No Atlantico Sul: Interpretacao Sismica E Controle TectonoEstratigrafino Na Bacia De Santos. In Mohriak, W., Szatmari, P. \& Anjos, S.M.C. Sal: Geologia e Tectonica, Exemplos nas Basicas Brasileiras., Beca Edicoes Ltda, Sao Paulo, Brasil, 340-359.

GE, Z., GAWTHORPE, R.L., ROTEVATN, A. AND THOMAS, M.B., 2017. Impact of normal faulting and pre-rift salt tectonics on the structural style of salt-influenced rifts: the Late Jurassic Norwegian Central Graben, North Sea. Basin Research, 29, 674-698.

GLENNIE, K.W., HIGHMAN J., \& STEMMERIK, L. (2003) Permian. In: The Millennium Atlas: petroleum geology of the central and northern North Sea (Ed by D. Evans, C. Graham, A. Armour \& P. Bathurst), pp. 91-103. The Geological Society of London, London.

GOLDSMITH, P.J., HUDSON, G. \& VAN VEEN, P. (2003) Triassic. In: The Millennium Atlas: petroleum geology of the central and northern North Sea (Ed by D. Evans, C. Graham, A. Armour \& P. Bathurst), pp. 105-127. The Geological Society of London, London.

HODGSON, N.A., FARNSWORTH, J. \& FRASER, A.J. (1992) Salt-related tectonics, sedimentation and hydrocarbon plays in the Central Graben, North Sea, UKCS. In: Exploration Britain: Geological Insights for the Next Decade. (Ed. by R.F.P. Hardman), Geol. Soc. London Spec. Publ., 67, 31-63. 
HSÜ, K.J. (1972) Origin of saline giants: a critical review after the discovery of the Mediterranean evaporite. Earth-Science Reviews, 8, 371-396.

HUDEC, M.R. \& JACKSON, M.P.A. (2007) Terra infirma: Understanding salt tectonics. Earth- Science Reviews, 82, 1-28.

JACKSON, M.P.A., VENDEVILLE, B.C. \& ELA-SCHULTZ, D.D. (1994) Structural dynamics of salt systems. Annual Review of Earth and Planetary Sciences, 22, 93-117.

JACKSON, M.P.A. \& VENDEVILLE, B.C. (1994) Regional extension as a geologic trigger for diapirism. Geological Society of America Bulletin, 106, 57-73.

JACKSON, M.P.A. \& HUDEC, M.R., 2017. Salt tectonics: Principles and practice. Cambridge University Press.

JACKSON, C.A-L. \& LARSEN, E. (2008) Temporal constraints on basin inversion provided by 3D seismic and well data: a case study from the SVG. Basin Ressearch, 20, 397-417.

JACKSON, C.A-L. \& E. LARSEN (2009) Temporal and spatial development of a gravity-driven normal fault array: Middle-Upper Jurassic, South Viking Graben, northern North Sea. J. Struct. Geol., 31, 388 -402 .

JACKSON, C.A-L., KANE, K.E. \& LARSEN, E (2010) Structural evolution of minibasins on the Utsira High, northern North Sea; implications for Jurassic sediment dispersal and reservoir distribution. Pet. Geosci., 16, 105-120.

JACKSON, C.A-L. \& LEWIS, M.M (2013) Physiography of the NE margin of the Permian Salt Basin: new insights from 3D seismic reflection data. Journal of the Geological Society, 170, 857-860.

JACKSON, C.A-L. \& LEWIS M.M, (2016) Structural style and evolution of a salt-influenced rift basin margin: the impact of variations in salt composition and the role of polyphase extension. Basin Research, $28,81-102$. 
JACKSON, C.A.L., RODRIGUEZ, C.R., ROTEVATN, A., AND BELL, R.E., 2014a, Geological and geophysical expression of a primary salt weld: An example from the Santos Basin, Brazil: Interpretation, v. 2, p. SM77-SM89.

JACKSON, C.A-L. \& STEWART, S.A. (2017) Composition, Tectonics, and Hydrocarbon Significance of Zechstein Supergroup Salt on the United Kingdom and Norwegian Continental Shelves: A Review. In Permo-Triassic Salt Provinces of Europe, North Africa and the Atlantic Margins (175-201).

KANE K.E., C.A-L. JACKSON \& E. LARSEN (2010) Normal fault growth and fault-related folding in a salt-influenced rift basin: South Viking Graben, Offshore Norway. J. Struct. Geol., 32 (4), 490-506.

KNOTT, S.D., BURCHELL, M.T., JOLLEY, E.J. \& FRASER, A.J. (1993) Mesozoic to Cenozoic plate reconstructions of the North Atlantic and hydrocarbon plays of the Atlantic margins. In: Petroleum Geology of Northwest Europe: Proceedings of the $4^{\text {th }}$ Conference (Ed. by J.R. Parker), pp. 953-974.

KNOTT, S.D. (2001) Gravity-driven crustal shortening in failed rifts. J. Geol. Soc., 158, 193-196.

KOYI, H., JENYON, M.K. \& PETERSON, K. (1993) The effect of basement faulting on diapirism. $J$. Petrol. Geol., 16, 285-312.

KRZYWIEC, P. (2012) Mesozoic and Cenozoic evolution of salt structures within the Polish Basin: An overview. In: Salt Tectonics, Sediment and Prospectivity. (Ed. by G.I. Alsop, S.G. Archer, A.J. Hartley, N.T. Grant, R. Hodgkinson), Geol. Soc. London Spec. Publ., 363, 381-394.

KUPFER, D.H., 1968, Relationship of internal to external structure of salt domes, in Braunstein, J., ed., Diapirism and Diapirs: American Association of Petroleum Geologists Memoir 8, p. 79-80.

LEWIS, M.M., JACKSON, C.A-L. \& GAWTHORPE, R.L. (2013) Salt-influenced normal fault growth and forced folding: The Stavanger Fault System, North Sea. Journal of Structural Geology, 54, 156-173. 
LYNGSIE, S.B., THYBO, H. \& RASMUSSEN, T.M. (2006) Regional geological and tectonic structures of the North Sea area from potential field modelling. Tectonophysics, 413, 147-170.

MARSH, N., IMBER, J., HOLDSWORTH, R.E., BROCKBANK, P. \& RINGROSE, P. (2009) The structural evolution of the Halten Terrace, offshore Mid-Norway: extensional fault growth and strain localisation in a multi-layer brittle-ductile system. Basin Res., 22, 195-214.

MATTHEWS, W.J., HAMPSON, G.J., TRUDGILL, B.D. \& UNDERHILL, J.R. (2007) Controls on fluviolacustrine reservoir distribution and architecture in passive salt diapir provinces: insights from outcrop

MCKIE, T. (2017) Paleogeographic Evolution of Latest Permian and Triassic Salt Basins in Northwest analogs. Am. Assoc. Petrol. Geol. Bull., 91, 1367-1403. Europe. In Permo-Triassic Salt Provinces of Europe, North Africa and the Atlantic Margins, 159-173.

MILTON, N.J. (1993) Evolving depositional geometries in the North Sea Jurassic rift. In: Petroleum Geology of Northwest Europe: Proceedings of the 4th Conference (Ed by J.R. Parker), pp. 425-442. Geological Society London.

MOREIRA, J.L.P., MADEIRA, C., GIL, J.A. \& MACHADO, M.A.P. (2007) Bacia De Santos. Bulletin Geociencias Petrobras, 15, 531-549.

PEGRUM, R.M. \& LJONES, T.E. (1984) 15/9 Gamma gas field offshore Norway, new trap type for the North Sea basin with regional structural implications. AAPG Bull., 68, 874-902.

PENGE, J., TAYLOR, B., HUCKERBY, J.A. \& MUNNS, J.W. (1993) Extension and salt tectonics in the East Central Graben. In: Petroleum Geology of Northwest Europe: Proceedings of the 4th Conference (Ed. by J.R. Parker), pp. 1197-1210. Geological Society of London.

RICHARDSON, N.J., UNDERHILL, J.R. \& LEWIS, G. (2005) The role of evaporite mobility in modifying subsidence patterns during normal fault growth and linkage, Halten Terrace, Mid-Norway. Basin Res., 17, 203-223. 
ROBERTS, A.M., YIELDING, G., KUSZNIR, N.J., WALKER, I.M. \& DORN-LOPEZ, D. (1995)

Quantitative analysis of Triassic extension in the Northern Viking Graben. J. Geol. Soc., 152, 15-26.

ROWAN, M.G. \& WEIMER, P. (1998) Salt-Sediment interaction, Northern Green Canyon and Edwing

Rowan, M.G. (2014) Passive-margin salt basins: hyperextension, evaporite deposition, and salt tectonics. Basin Research, 26, 154-182.

SCHLUMBERGER (2009) Log Interpretation Charts. 2009 Edition, Schlumberger Publication.

SHELLEY, D.C. \& LAWTON, T.F. (2005) Sequence stratigraphy of tidally-influenced deposits in a saltMexico. Am. Assoc. Petrol. Geol. Bull., 89, 1157-1179.

SMITH, R.I., HODGSON, N., \& FULTON, M. (1993) Salt control on Triassic reservoir distribution, UKCS Central North Sea. In: Petroleum Geology of Northwest Europe: Proceedings of the $4^{\text {th }}$ Conference (Ed by J.R. Parker), pp. 547-557. Geological Society London.

SOTO, J.I., FLINCH, J.F. \& TARI, G. (2017) Permo-Triassic Basins and Tectonics in Europe, North Africa and the Atlantic Margins: A Synthesis. In Permo-Triassic Salt Provinces of Europe, North Africa and the Atlantic Margins, 3-41. Elsevier.

STEWART, S.A. (2018) Hormuz salt distribution and influence on structural style in NE Saudi Arabia. Petroleum Geoscience, 24, 143-158.

STEWART, S.A. \& COWARD, M.P. (1995) Synthesis of salt tectonics in the southern North Sea, UK. Mar. Petrol. Geol., 12, 457-475. 
STEWART, S.A., HARVEY, M.J., OTTO, S.C. \& WESTON, P.J. (1996) Influence of salt on fault geometry: examples from the UK salt basins. In: Salt Tectonics (Ed. by Alsop G.I., Blundell D.J., Davison I.) Geol. Soc. Spec. Publ., 100, 175-202.

STEWART, S.A. \& CLARK, J.A. (1999) Impact of salt on the structure of the Central North Sea hydrocarbon fairways. In: Petroleum Geology of Northwest Europe: Proceedings of the 5th Conference (Ed by A. J. Fleet \& S.A.R. Boldy), pp. 179-200. Geological Society London.

STEWART, S.A. (2007) Salt tectonics in the North Sea Basin: a structural style template for seismic interpreters. In: Deformation of the Continental Crust: The Legacy of Mike Coward (Ed. by A.C. Ries, 868

TAYLOR, J.C.M. (1990) Upper Permian-Zechstein. In: Introduction to the Petroleum Geology of the North Sea (Ed. by K.W. Glennie, $3^{\text {rd }}$ Edition). Blackwell Scientific Publications, 153-190.

THOMAS, D.W. \& COWARD, M.P. (1996) Mesozoic regional tectonics and South Viking Graben formation; evidence for localized thin- skinned detachments during rift development and inversion. Mar.

TRUDGILL, B., BANBURY, N. \& UNDERHILL, J. (2004) Salt evolution as a control on structural and stratigraphic systems: northern Paradox foreland basin, SE Utah, USA. In: Salt Sediment Interactions and hydrocarbon Prospectivity: Proceedings of $24^{\text {th }}$ Annual Gulf Coast Section SEPM Foundation Bob

TRUDGILL, B.D. (2011) Evolution of salt structures in the northern Paradox Basin: controls on evaporite deposition, salt wall growth and supra-salt stratigraphic architecture. Basin Res., 23, 208-238. 
912

913

914

915

916

917

918 919

TUCKER, M.E. (1991) Sequence stratigraphy of carbonate-evaporite basins: models and application to the Upper Permian (Zechstein) of northeast England and adjoining North Sea. Journal of the Geological Society, 148, pp.1019-1036.

TVEDT, A.B.M, ROTEVATN, A., JACKSON, C.A-L., FOSSEN, H. \& GAWTHORPE, R.L. (2013) Growth of normal faults in multilayer sequences: a 3D seismic case study from the Egersund Basin, Norwegian North Sea. Journal of Structural Geology, 55, 1-20.

UNDERHILL, J.R. \& PARTINGTON, M.A. (1993) Jurassic thermal doming and deflation in the North Sea: implications of the sequence stratigraphic evidence. In: Petroleum Geology of Northwest Europe: Proceedings of the 4th Conference (Ed. by J.R. Parker), pp. 337-345. Geological Society, London.

VENDEVILLE, B.C. \& JACKSON, M.P.A. (1992) The rise of diapirs during thin-skinned extension. Marine and Petroleum Geology, 9, 331-354.

WARREN, J.K. (2010) Evaporites through time: Tectonic, climatic and eustatic controls in marine and nonmarine deposits. Earth-Science Reviews, 98, 217-268.

WARREN, J.K. (2016) Evaporites: A geological compendium. Springer.

WILLIAMS, G.D. (1993) Structural models for the evolution of the North Sea area. In: Petroleum Geology of Northwest Europe: Proceedings of the 4th conference (Ed. by J.R. Parker), pp. 1083-1093. Geological Society of London.

WILSON, P., ELLIOTT, G.M., GAWTHORPE, R.L., JACKSON, C.A.-L., MICHELSEN, L. \& SHARP, I.R. (2013) Geometry and segmentation of an evaporite-detached normal fault array: the southern Bremstein Fault Complex, offshore mid-Norway. J. Struct. Geol., 51, 74-91.

WITHJACK, M.O. \& CALLAWAY, S. (2000) Active normal faulting beneath a salt layer: an experimental study of deformation patterns in the cover sequence. AAPG Bull., 84, 627-651. 
ZANELLA, E. \& COWARD, M.P. (2003) Structural framework. In: The Millenium Atlas: petroleum geology of the central and northern North Sea (Ed. by D. Evans, C. Graham, A. Armour \& P. Bathurst), pp. 45-59. The Geological Society of London.

ZIEGLER, P.A. (1990) Tectonic and paleogeographic development of the North Sea rift system. In: Tectonic Evolution of the North Sea Rifts (Ed. by D. Blundell \& A.D. Gibbs), pp. 1-36. Clarendon Press, Oxford.

ZIEGLER, P.A. (1992) Geodynamic of rifting and implications for hydrocarbon habitat, Tectonophysics, 215, 221-253.

\section{FIGURE CAPTIONS}

Fig. 1. Simplified structural basemap of the study area indicating the position of major basement-involved normal faults, sub-basins and intra-basin structural highs. FGS=Fladen Ground Spur; SVG=South Viking Graben; WGG=Witch Ground Graben; SB=Sleipner Basin; ST=Sleipner Terrace; UH=Utsira High; LD=Ling Depression; SH=Sele High; $\mathrm{AG}=$ Åsta Graben; EB=Egersund Basin; SP=Stavanger Platform; LFB $=$ Lista Fault Blocks; N-DB=Norwegian-Danish Basin. The seismic and borehole dataset used in this study is shown. The regional geographical setting of the North (NPB) and South (SPB) Permian basins is shown in the inset map.

Fig. 2. Composite stratigraphic column for the study area. The regional tectono-stratigraphic significance of the various stratigraphic units is indicated (modified from Jackson and Larsen, 2009).

Fig. 3. (a) Map showing the principal lithologies in the Zechstein Supergroup (Upper Permian) along the northwestern margin of the NPB (UK sector of the Central Graben) and their relationship to the main basement-involved structural elements (modified from Stewart, 2007). Four depositional zones (DZs) are depicted (1-4), which are differentiated based on their proportion of halite (Clark et al., 1998). Areas of syn-depositional (i.e. Lopingian) and immediately post-depositional (i.e. Triassic) salt flow are indicated. The red box represents the area considered in our study. Abbreviations for tectonic features are the same as for Fig. 1. (b) Schematic section showing the idealized lateral lithology variability observed between the centre and the margin of an evaporite basin (based on the west margin of the Southern Permian Basin; see 
Taylor, 1990). Four DZs corresponding to those shown in (a) and which are defined by varying proportions of halite, are recognised.

Fig. 4. Density (RHOB) vs. sonic (DT) cross-plot illustrating the petrophysical expression of the evaporite and non-evaporite lithologies recovered in cuttings from the Zechstein Supergroup. For the location of boreholes see Fig. 1. Note the strong (anhydrite) to very strong (halite) differentiate between evaporite and non-evaporite lithologies. 'Ideal' values reported by Schlumberger (2009) for RHOB and DT are indicated by a black dot with a red outline (halite) and a black dot with a blue outline (anhydrite). Note that these ideal values are for pure mineral species (i.e. they do not account for impure rock types that contain a mix of minerals with different physical characteristics).

Fig. 5. (a) Sonic (DT) vs. gamma-ray (GR) and (b) density (RHOB) vs. gamma-ray (GR) cross-plot illustrating the petrophysical expression of claystone and carbonate recovered in cutting from the Zechstein Supergroup. For the location of boreholes see Fig. 1. Note the strong overlap between these two nonevaporite lithologies.

Fig. 6. Regional Zechstein Supergroup isochron based on mapping of 2D seismic profiles shown in Fig. 1. The present depositional/erosional limit of the Zechstein Supergroup is shown, in addition to the locations of major basement-involved normal faults and key boreholes. Due to gridding artefacts (i.e. spatial aliasing) resulting from gridding of relatively widely spaced $(>5 \mathrm{~km}) 2 \mathrm{D}$ seismic profiles, the detailed geometry of individual salt structures and their flanking depocentres (minibasins) is poorly constrained; i.e. structures appearing as isolated, sub-circular stocks might in fact form part of much more continuous, elongate walls. See the caption for Fig. 1 for the abbreviations for key structural elements. For clarity, only selected wells are shown; see Fig. 1 for the spatial of all wells, and Figs 7-10 and 14 for well data.

Fig. 7. Stratigraphic panel (a) and corresponding interpreted seismic profile (b) across the South Viking Graben, Utsira High, Sleipner Terrace and Ling Depression. The stratigraphic panel illustrates the lithological variability between basin centre (i.e. South Viking Graben and Ling Depression) and basin margin (i.e. Utsira High, Sleipner Terrace) locations. The stratigraphic panel is flattened on the top of the Zechstein Supergroup and the lithologies defined in the panel are based on cuttings data. The seismic profile illustrates the structural setting of the wells and their relationships to salt structures. The location of the profile is shown in Fig. 1. GBFZ=Graben Boundary Fault Zone. 
Fig. 8. Stratigraphic panel (a) and corresponding interpreted seismic profile (b) across the eastern margin of the South Viking Graben. The stratigraphic panel illustrates the lithological variability observed along the basin margin. The stratigraphic panel is flattened on the top of the Zechstein Supergroup and the lithologies defined in the panel are based on electrofacies characterisation (see Fig. 4 and text for further details). The seismic profile illustrates the structural setting of the wells and their relationships to salt structures. The location of the profile is shown in Fig. 1.

Fig. 9. Stratigraphic panel (a) and corresponding interpreted seismic profile (b) across the Sleipner Terrace and Ling Depression. The stratigraphic panel illustrates the lithological variability between basin centre (i.e. western part of the Ling Depression; 16/8-2) and basin margin (i.e. Sleipner Terrace and eastern part of the Ling Depression; 16/9-1) locations. The stratigraphic panel is flattened on the top of the Zechstein Supergroup and the lithologies defined in the panel are based on cuttings data. The seismic profile illustrates the structural setting of the wells and their relationships to salt structures. The location of the profile is shown in Fig. 1.

Fig. 10. Stratigraphic panel (a) and corresponding interpreted seismic profile (b) across the Ling Depression, Sele High and Åsta Graben. The stratigraphic panel illustrates the lithological variability observed between the basin centre (i.e. Ling and Åsta Graben) and an intra-basin structural high (i.e. Sele High). The stratigraphic panel is flattened on the top of the Zechstein Supergroup and the lithologies defined in the panel are based on electrofacies characterisation (see Fig. 4 and text for further details). The seismic profile illustrates the structural setting of the wells and their relationships to salt structures. The location of the profile is shown in Fig. 1.

Fig. 11. Seismic (a) and geoseismic (b) sections across the eastern margin of the Ling Depression and the western margin of the Sele High; in this position, the boundary between the two structural domains is not fault controlled, and is instead defined by a broadly W- to SW-dipping ramp. This profile covers an area where the Zechstein Supergroup is thought to be relatively halite rich (DZ3 of Clark et al., 1998). The location of the profile is shown in Fig. 1.

Fig. 12. Seismic (a) and geoseismic (b) sections across the eastern margin of the Ling Depression and the western margin of the Sele High; in this position, the boundary between the two structural domains is defined by a relatively large-displacement (600 ms TWT), basement-involved normal fault (F1) (cf. Fig. 11). This profile covers an area where the Zechstein Supergroup is thought to pass from being relatively 
1018 halite-rich in a deep basin setting (i.e. the Ling Depression; DZ3 of Clark et al., 1998), to being relatively 1019 halite-poor on the basin margin (i.e. the Sele High). Note that the development of thin-skinned, salt1020 detached normal faults on the Sele High suggests some halite is present, thus this area may represent DZ2 1021 of Clark et al. (1998), rather than DZ1. The location of the profile is shown in Fig. 1.

1023 Fig. 13. Seismic (a) and geoseismic (b) sections across the eastern margin of the Ling Depression, the 1024 southern Sele High, and the western Egersund Basin; in this position, the eastern and western boundaries 1025 of the Sele High are defined by relatively large-displacement (300-1500 ms TWT), basement-involved 1026 normal faults (F1 and F3). This profile covers an area where the Zechstein Supergroup is thought to pass 1027 from being relatively halite-rich in deep basin settings (i.e. the Ling Depression and Egersund Basin; DZ310284 of Clark et al., 1998), to being relatively halite-poor on the basin margin (i.e. the Sele High). Note that 1029 the development of relatively small diapirs and shallow minibasins on the Sele High suggests some halite 1030 is present, thus this area may represent DZ2 of Clark et al. (1998), rather than DZ1. The location of the profile is shown in Fig. 1.

Fig. 14. Stratigraphic panel (a) and corresponding interpreted seismic profile (b) across the eastern part of the Egersund Basin and the Lista Fault Blocks. The stratigraphic panel illustrates the lithological variability observed near the basin margin. The stratigraphic panel is flattened on the top of the Zechstein Supergroup and the lithologies defined in the panel are based on electrofacies characterisation (see Fig. 4 and text for further details). The seismic profile illustrates the structural setting of the wells and their relationships to salt structures. The location of the profile is shown in Fig. 1. Note that 10/7-1, which appears to penetrate the lower flank of a diapir, is projected into the section and actually penetrates the immediate footwall of a basin-bounding fault (see Fig. 15).

Fig. 15. Regional map showing the basin-scale distribution of depositional zones (sensu Clark et al., 1998), 1043 a proxy for bulk lithology, in the Zechstein Supergroup (ZSG). In the UK sector, the map is based on data 1044 published by Clark et al. (1998), Glennie et al. (2003), Stewart (2007), and Jackson et al. (2010); data 1045 presented in this study is used to constrain the map in the Norwegian sector. Note that boundaries between 1046 domains, especially within the deep basin (e.g. Egersund Basin, South Viking Graben, Ling Depression) 1047 and flanking ramps are uncertain and undoubtedly gradational; these boundaries are thus shown as dashed 1048 rather than solid lines. Where domain boundaries are fault-controlled, they are likely more abrupt. The area 1049 defined by light-pink (halite-rich DZ4; e.g. the Central Graben) and light-blue (moderately halite-poor DZ2; 1050 e.g. the Jæren High), immediately east and west of the median line between Norwegian and UK waters, is 
1051 inferred. Because of post-depositional salt flow, in particular from the halite-rich hangingwalls onto the

1052 adjacent fault-bound footwalls, originally halite-poor areas (DZ1 and 2) may now be characterised by 1053 variable thickness salt and salt diapirs (cf. areas of variable thickness salt and diapirism in Fig. 6). 1054 Abbreviations for tectonic features are the same as for Fig. 1.

1056 Fig. 16. Four end-member models that may account for the thickness and lithology variations observed in 1057 the Zechstein Supergroup (see also Jackson and Lewis, 2013). (A) Model 1 - thickness and lithology 1058 variations driven by post-depositional tectonics (e.g. normal faulting and regional thermal uplift) results in 1059 halite dissolution and the relative enrichment in non-halite lithologies at the basin margins and on intra1060 basin structural highs. Thicker, more halite-rich succession preserved in fault hangingwalls. (B) Model 2 1061 thickness and lithology variations driven by post-depositional flow of a heterogeneous Zechstein 1062 Supergroup (i.e. anhydrite-dominated basin margin, halite-dominated basin centre), with flow being 1063 strongly partitioned (i.e. mobile halite preferentially expelled from the basin margin into flanking salt 1064 structures, resulting in local enrichment of non-halite lithologies in areas where Zechstein Supergroup is 1065 thin). (C) Models 3 and 4 - thickness and lithology variations driven by pre- (Model 3) and/or syn- (Model 1066 4) depositional tectonics (e.g. normal faulting and regional thermal uplift). Halite deposition in high 1067 accommodation areas (e.g. basin centre) during sea-level lowstand (see t3) and carbonate/anhydrite 1068 deposition in low accommodation areas (e.g. basin margin) during sea-level highstand (see t4) (cf. Tucker, 1069 1991). In Model 4, variations in the thickness and lithology of the Zechstein Supergroup were simply 1070 augmented by syn-depositional faulting. T1-3=sea-level.

1071

1072 Table 1. Summary of the boreholes used in this study. GR=gamma ray; DT=sonic velocity; 1073 RHOB=density. See text for full discussion.

1075 Table 2. Petrophysical characteristics of evaporite and non-evaporite lithologies encountered in the 1076 Zechstein Supergroup; this is based on well cuttings, and is partly constrained by values reported by 1077 Schlumberger (2009) and Rider and Kennedy (2011) (values in brackets). Note that published values are 1078 for pure mineral species (i.e. they do not account for impure rock types that contain a mix of minerals with 1079 different physical characteristics). 


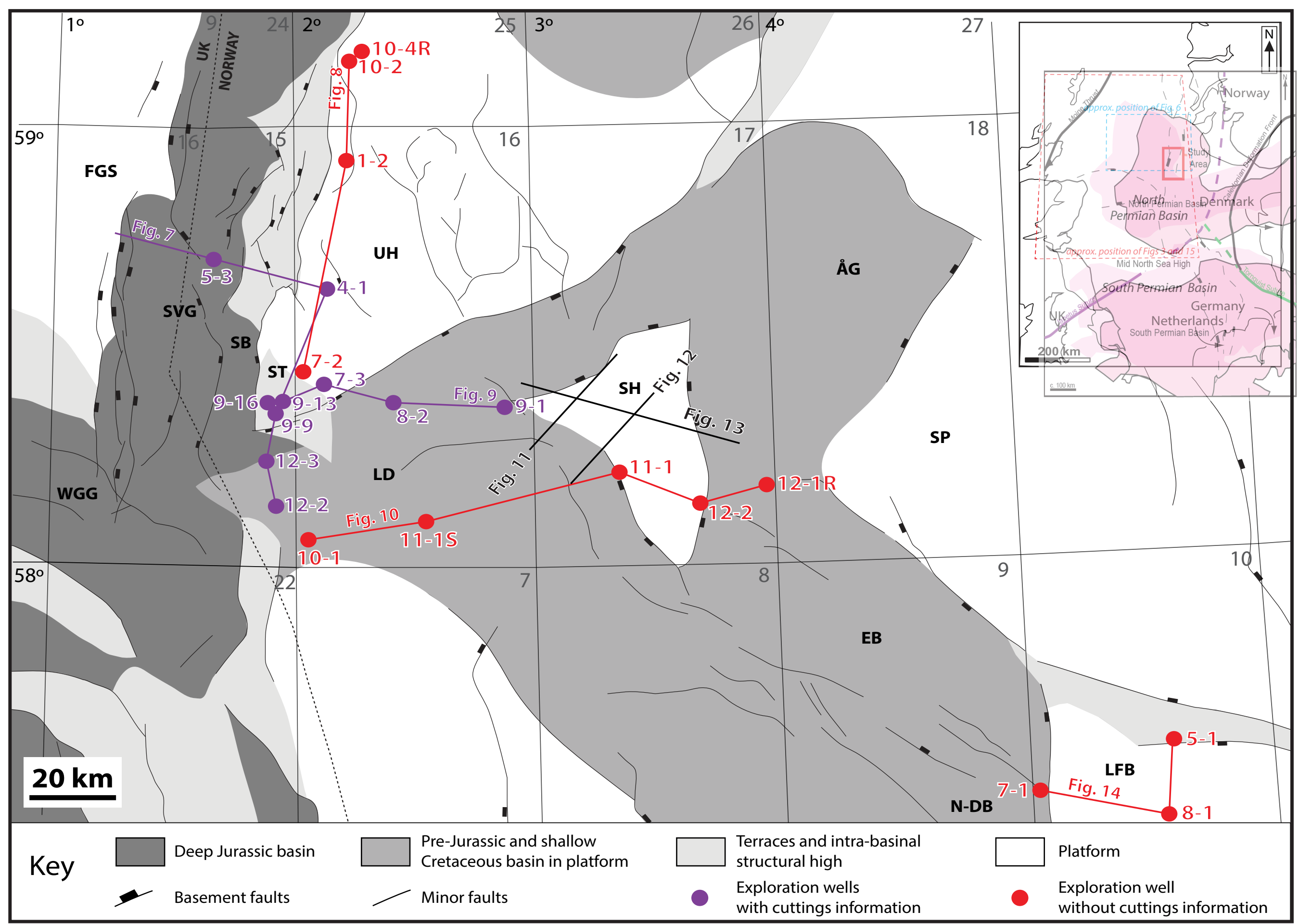

Figure 1 


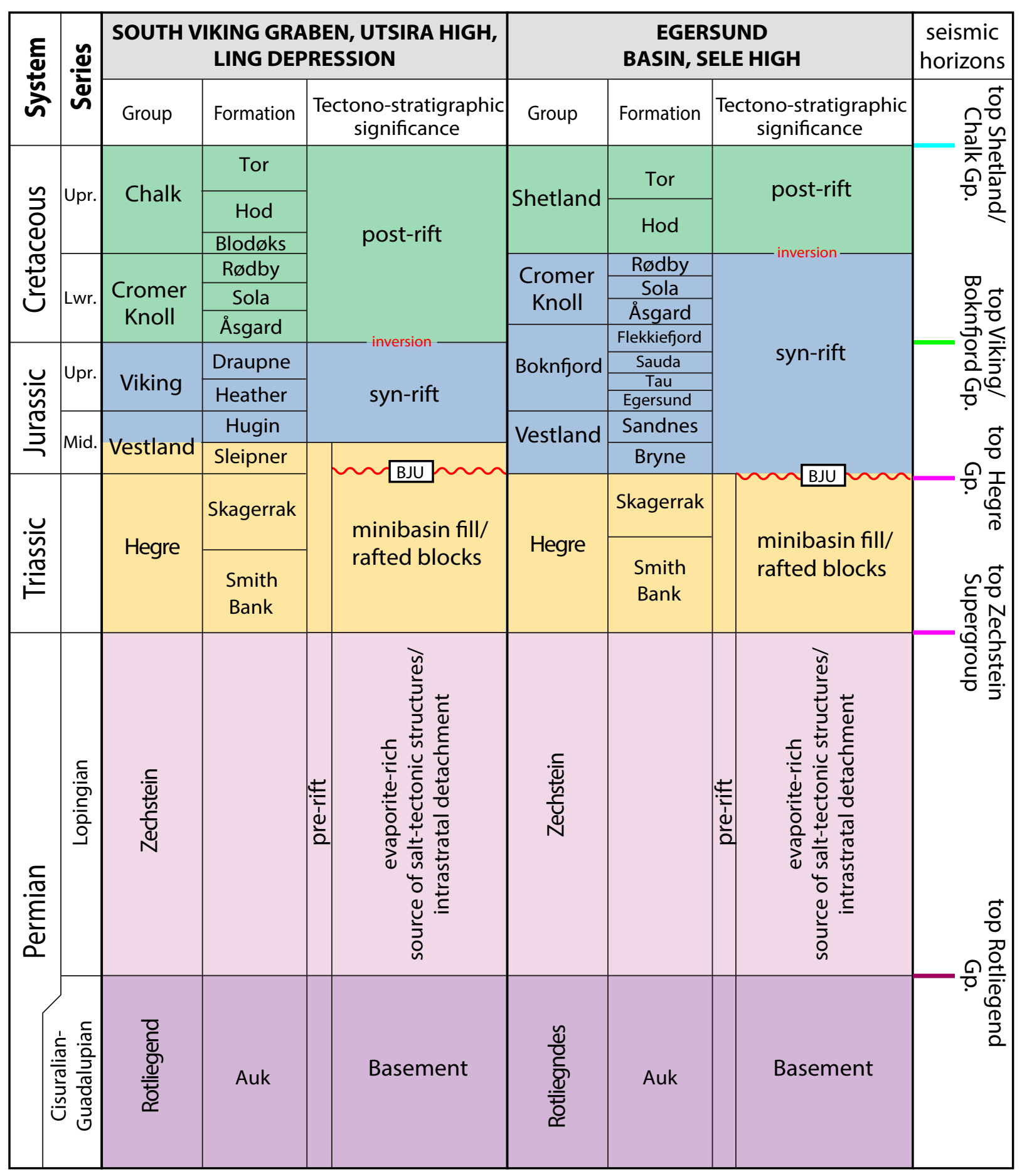

Figure 2 


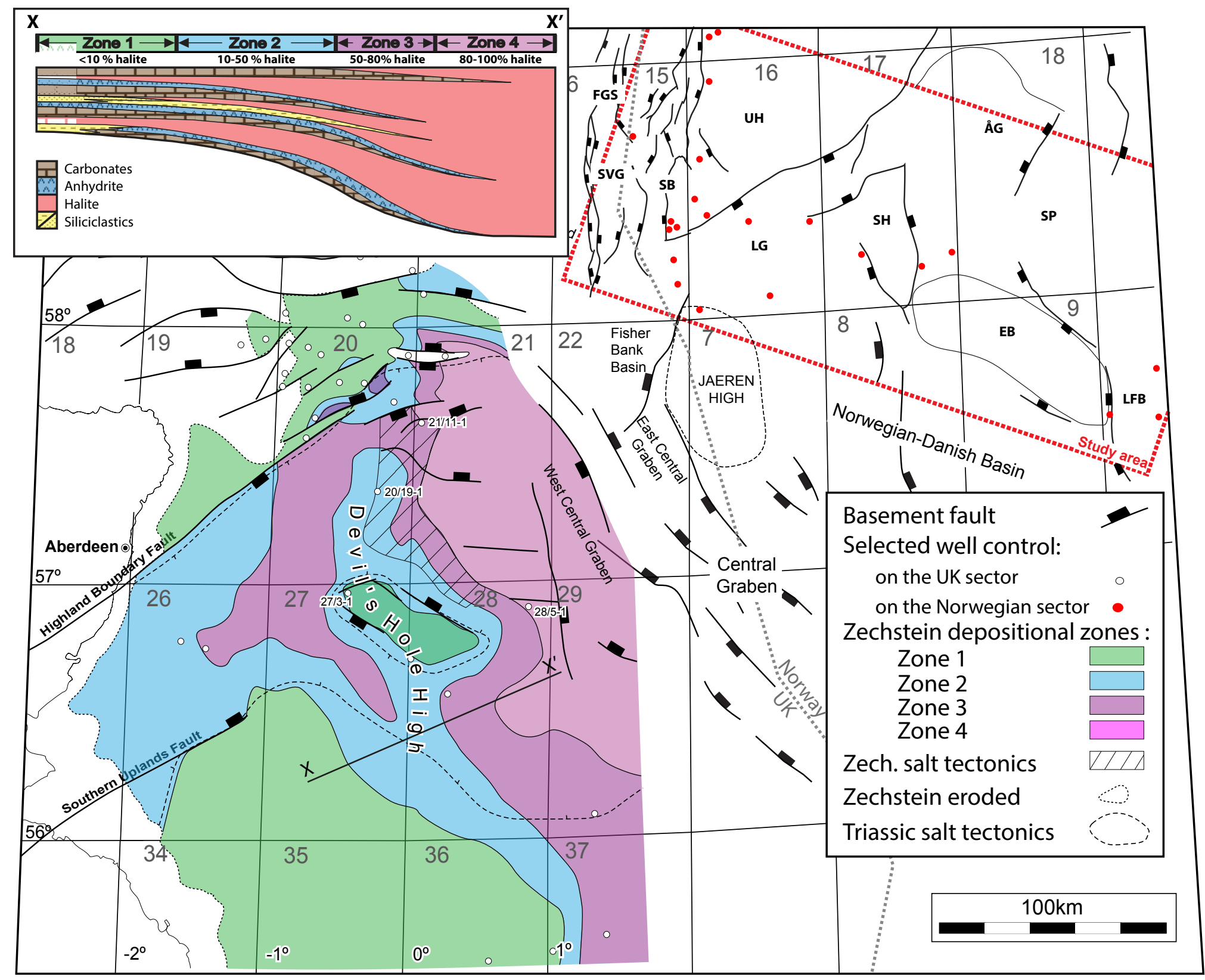

Figure 3 


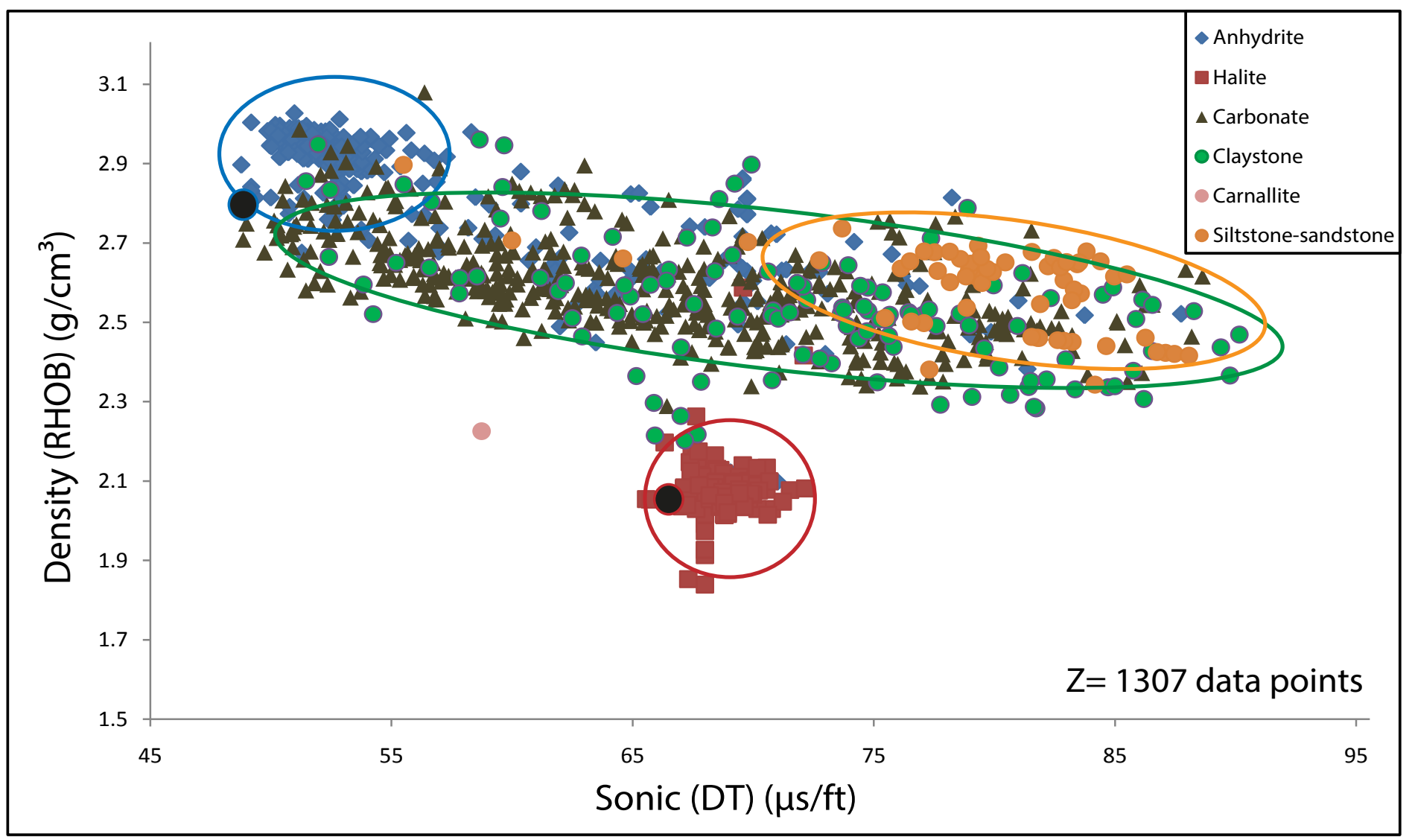

Figure 4 

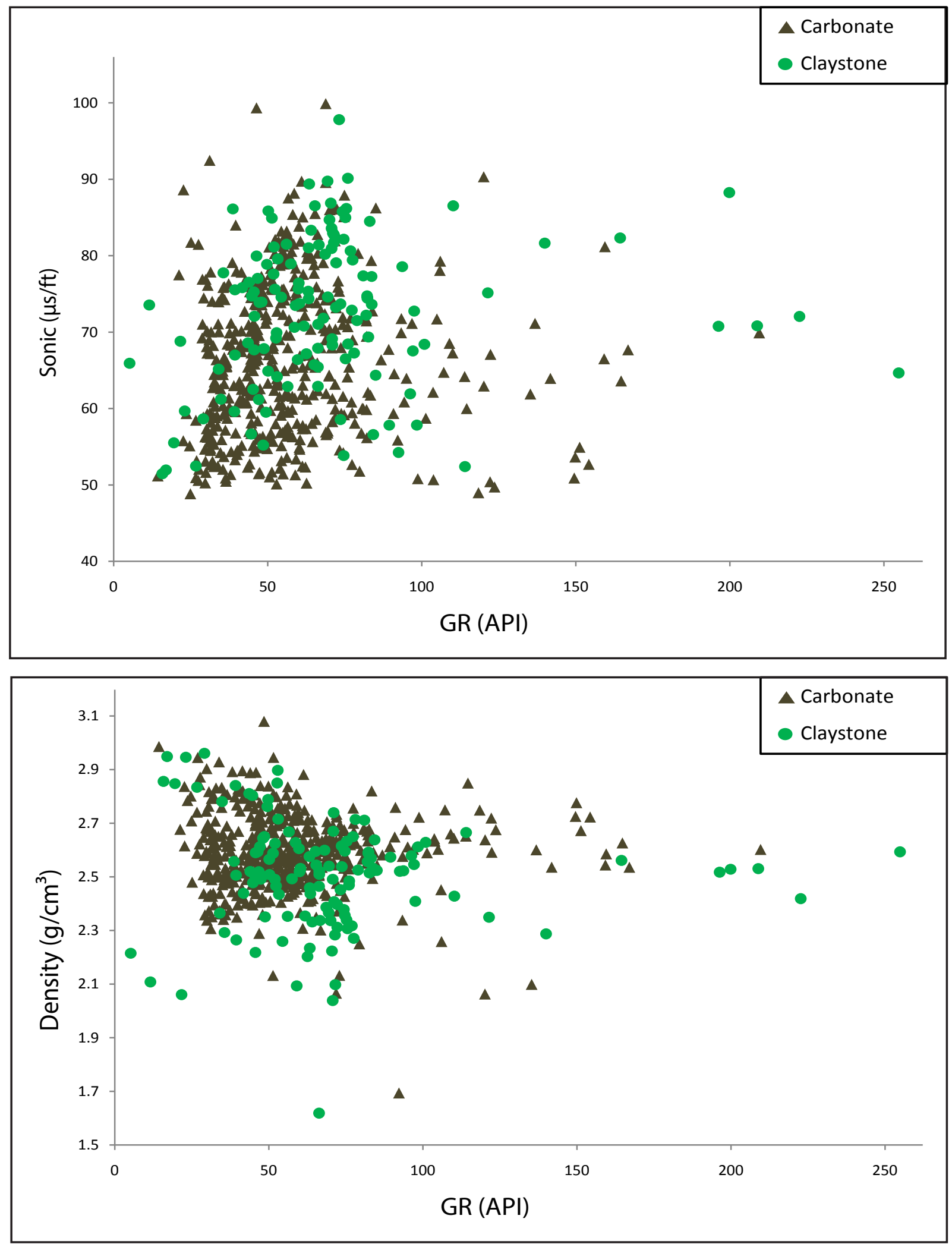

Figure 5 


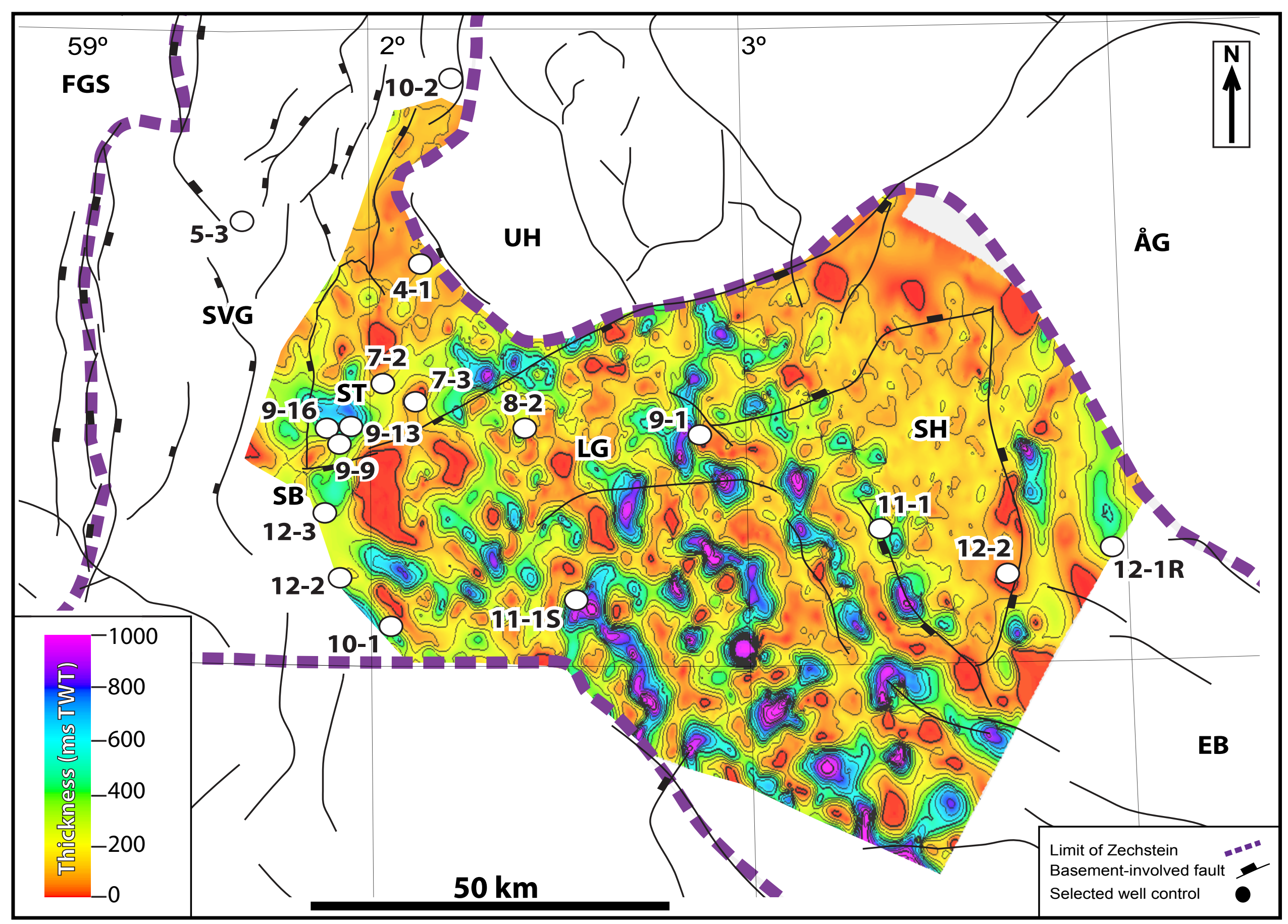

Figure 6 

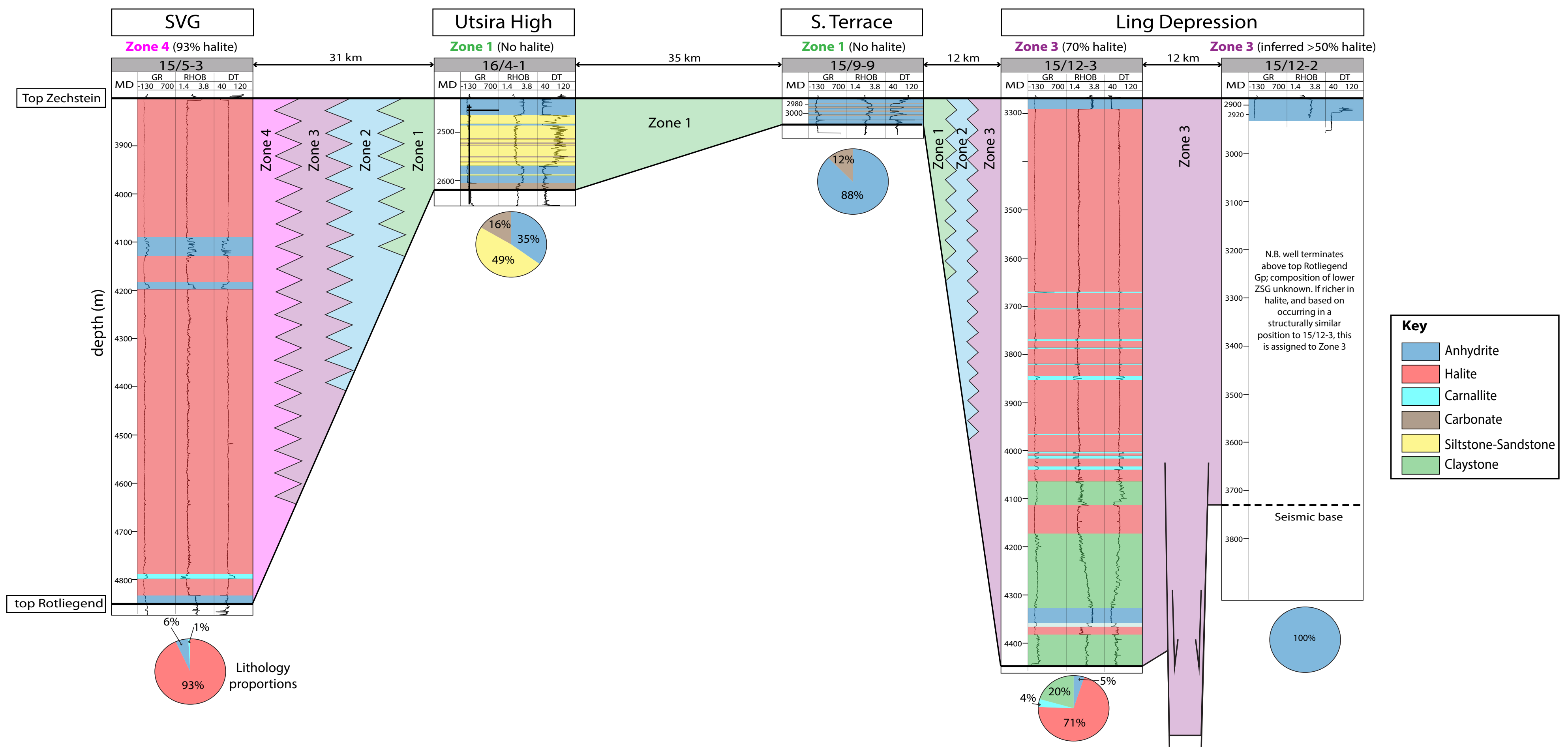

(B)

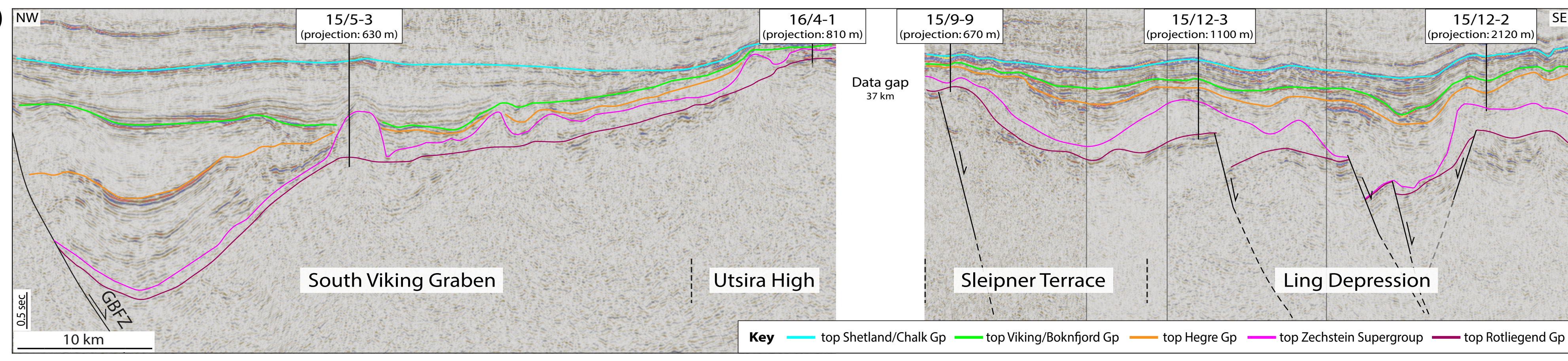

Figure 7 
Utsira High

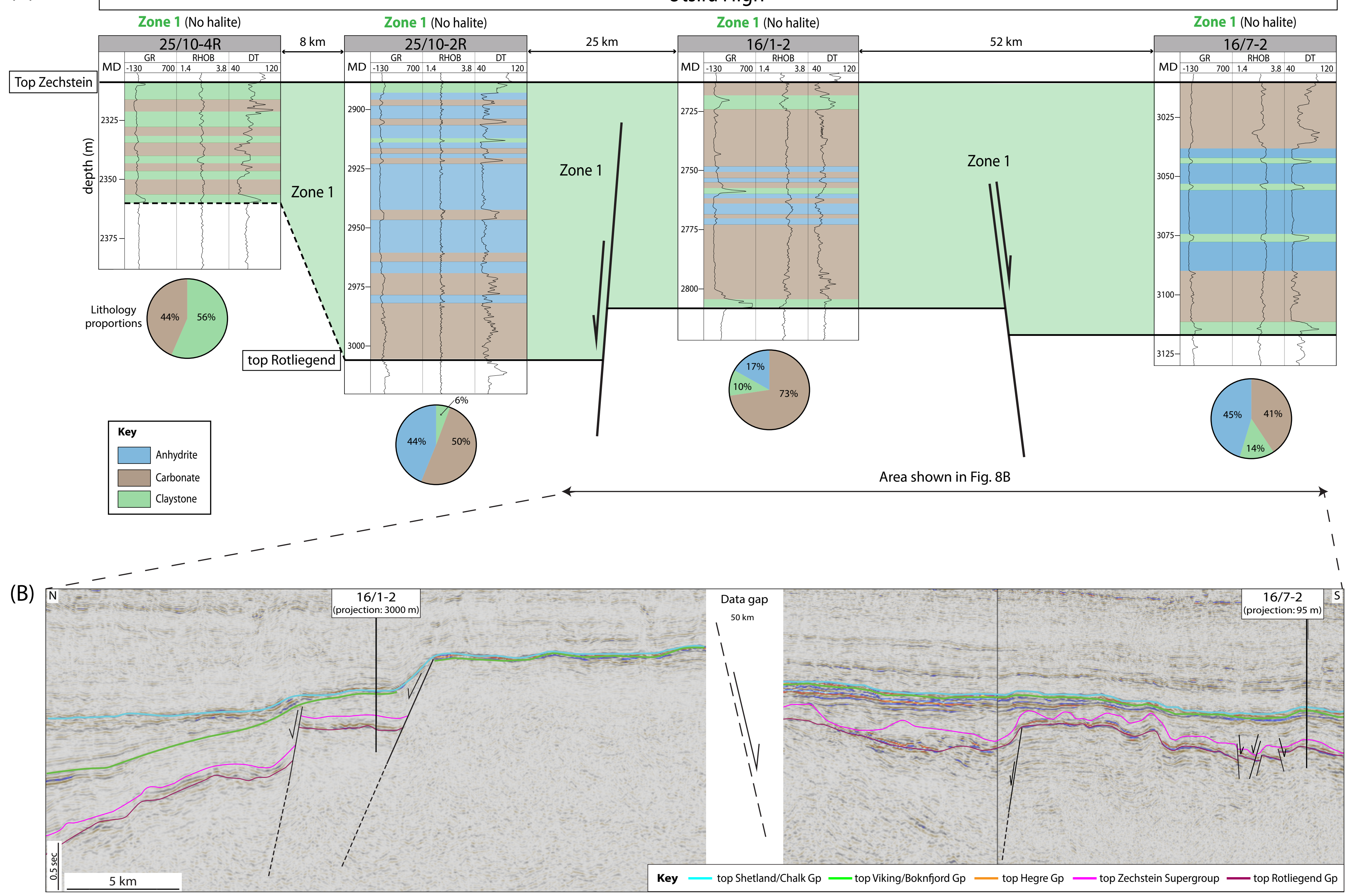

Figure 8 
Ling Depression

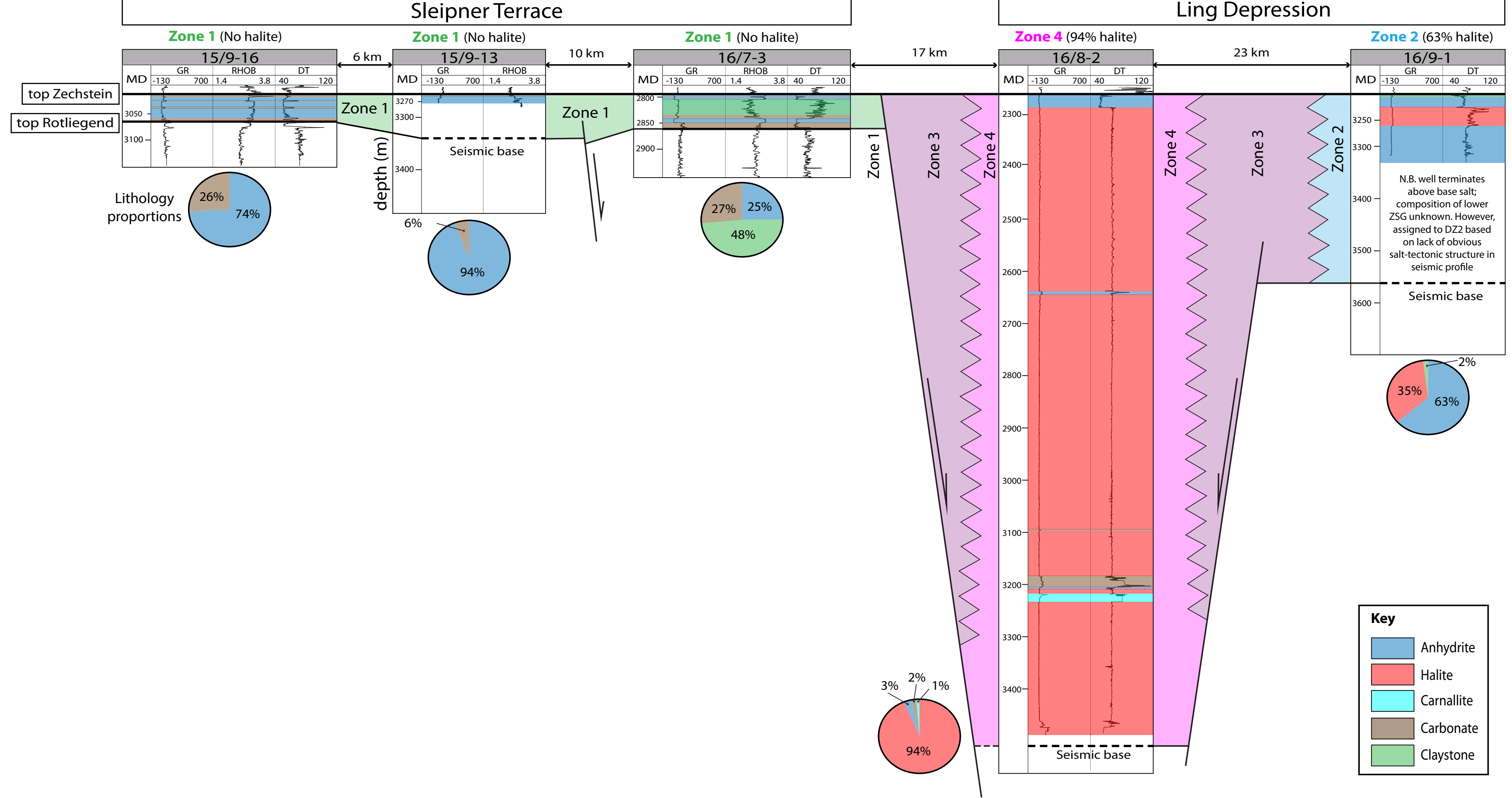

(B)

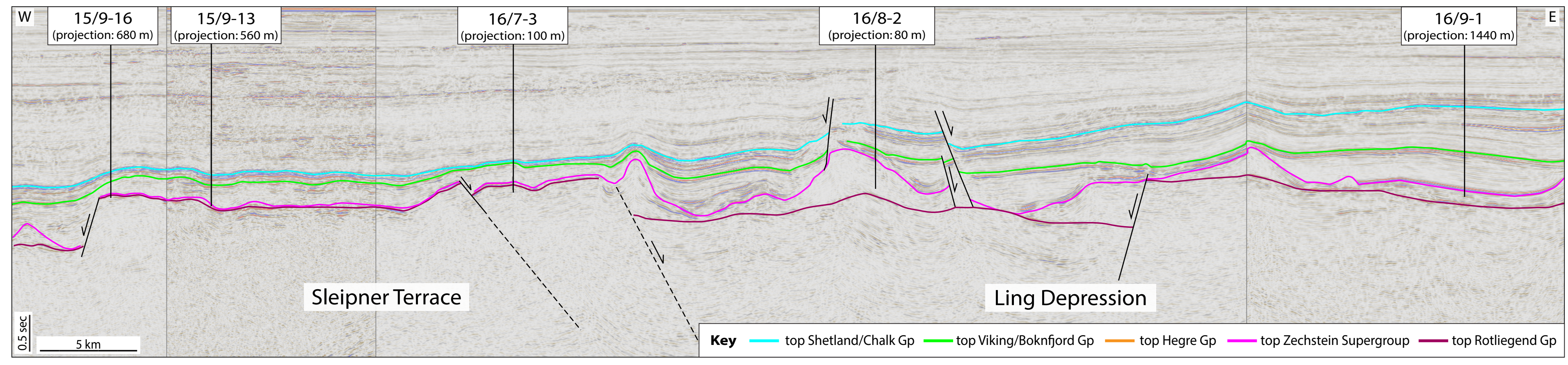




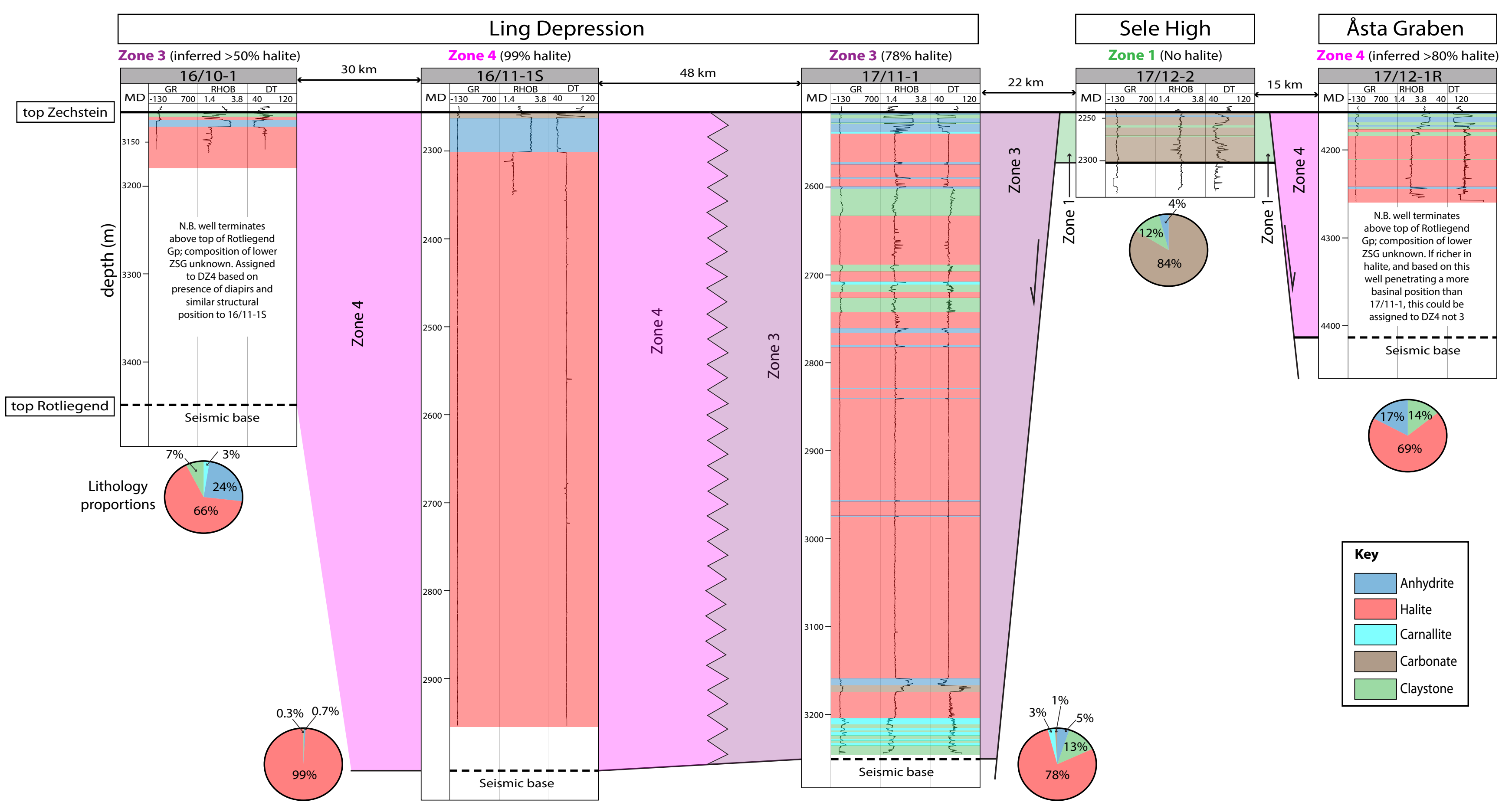

(B)

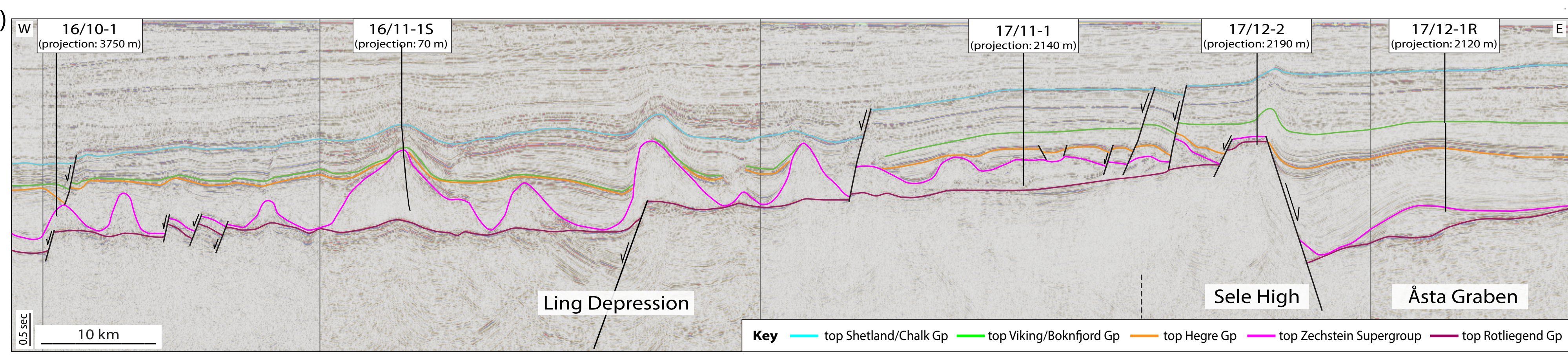

Figure 10 
Sele High

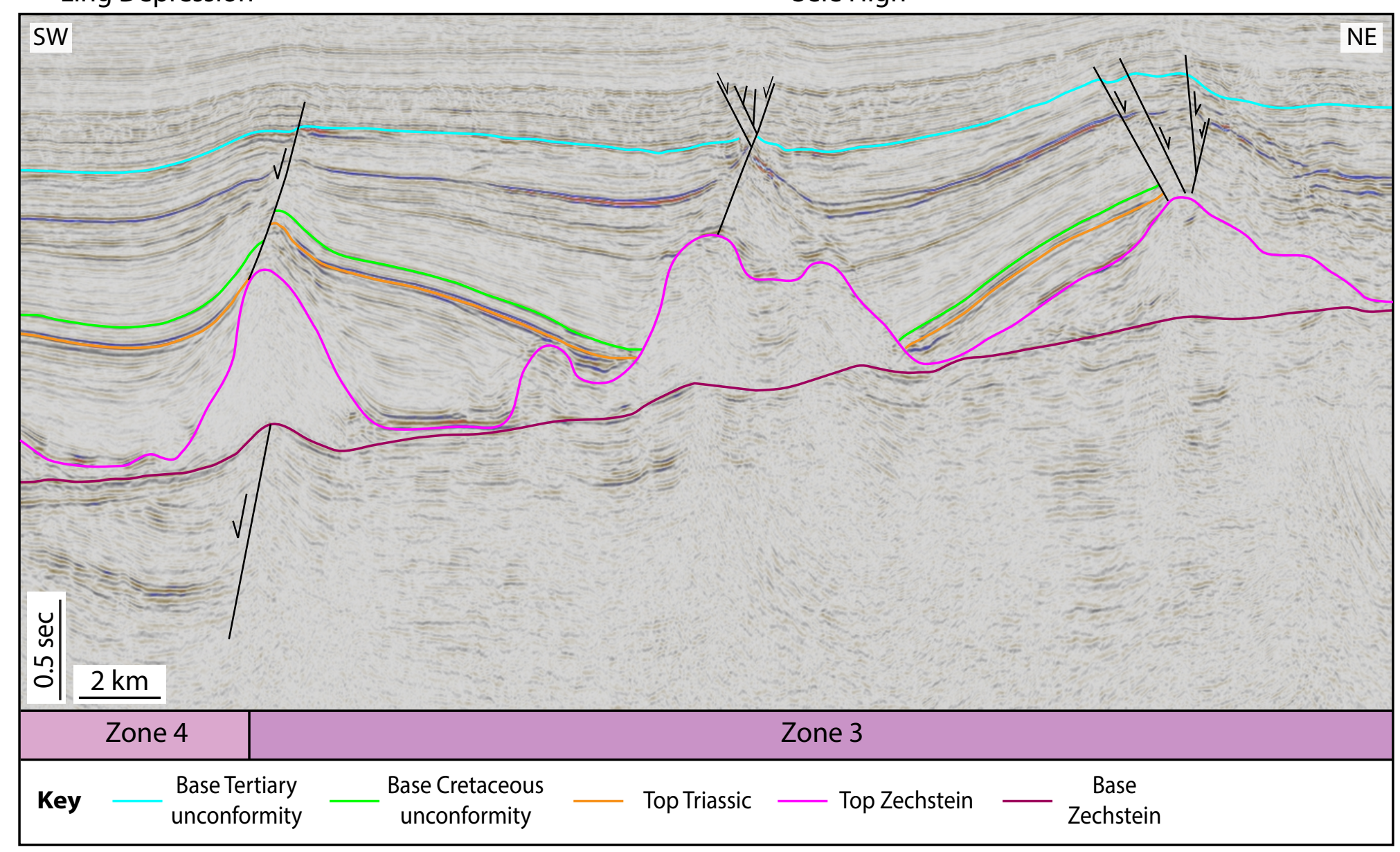

Figure 11 


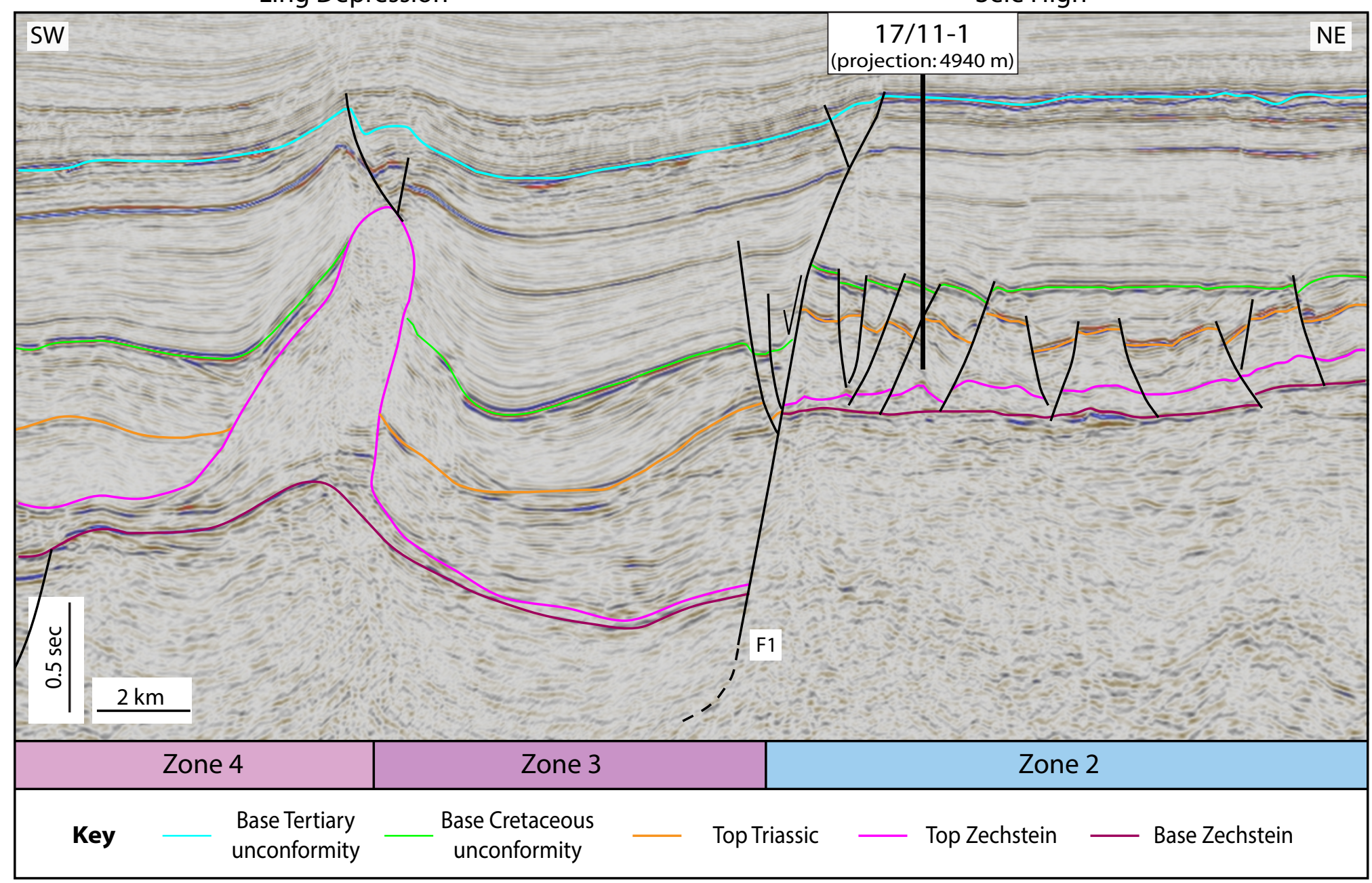

Figure 12 


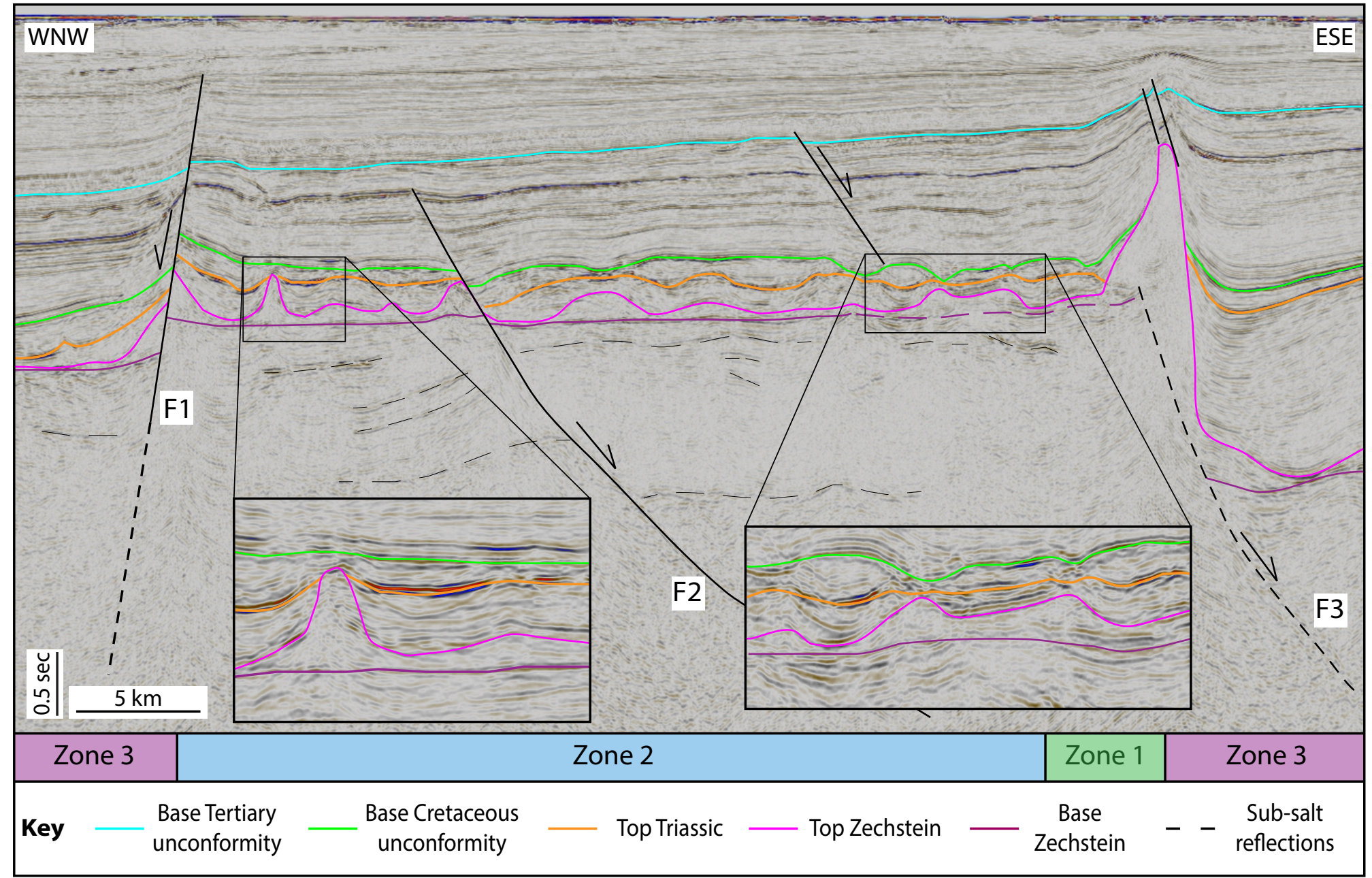

Figure 13 
Lista Fault Blocks
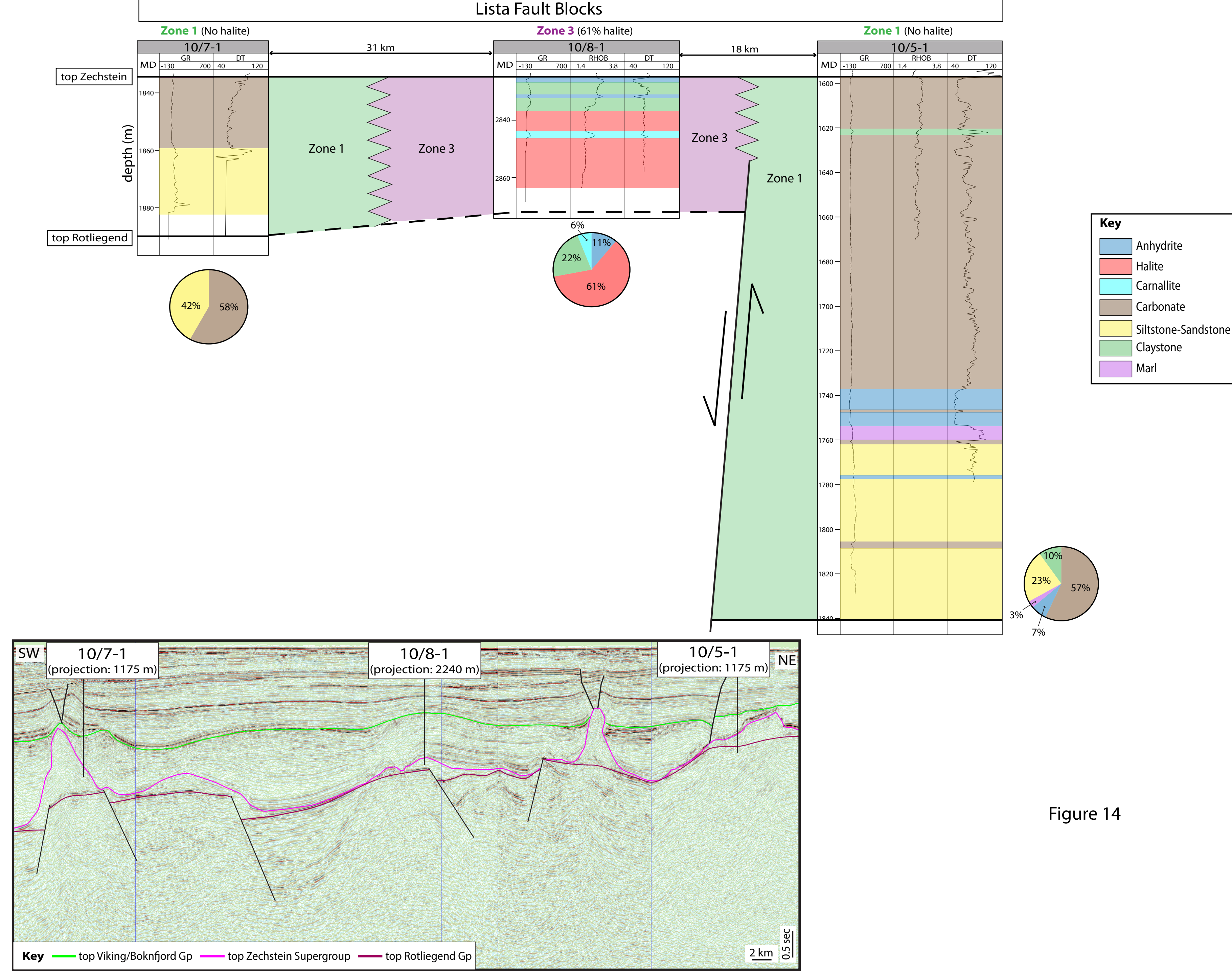

Figure 14 


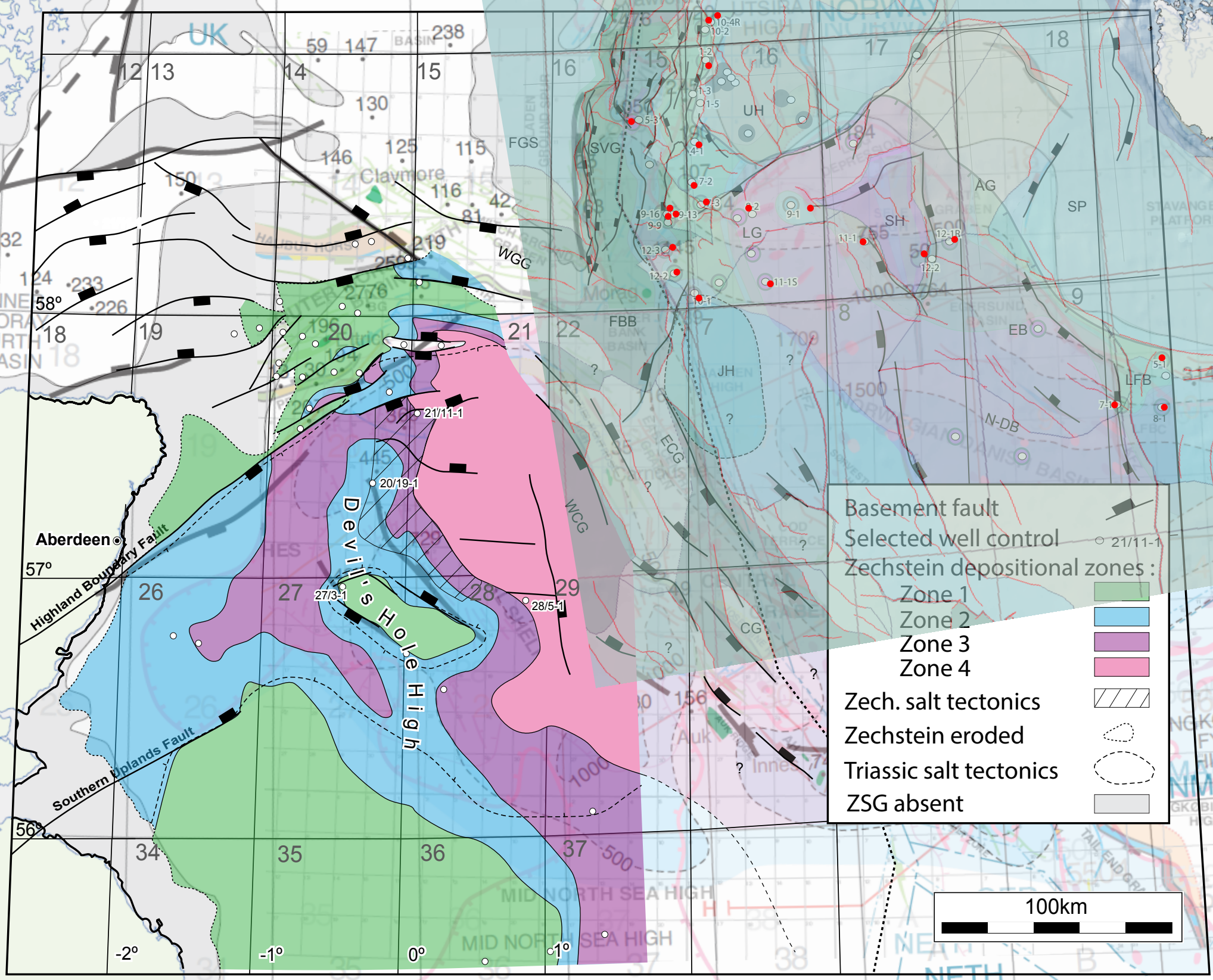

Figure 15 
Fig. 16

a)
Time 1

Basin margin $\rightarrow$ (B) $++++t_{+}^{+}$

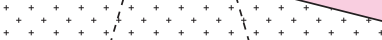

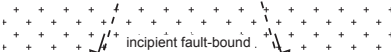

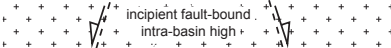

Time 1

b)

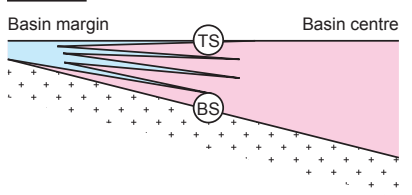

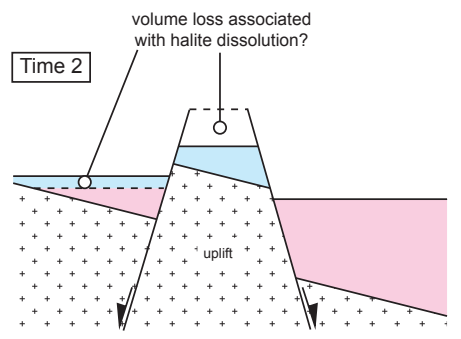

Time 2

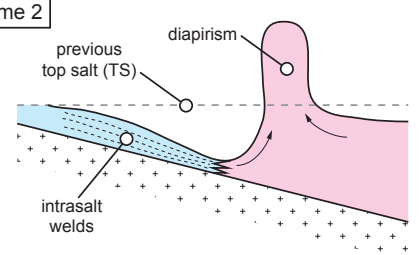

Key

$\square$ non-halite-dominated

halite-dominated

$+_{++}^{+}$subsalt
Time 1

))

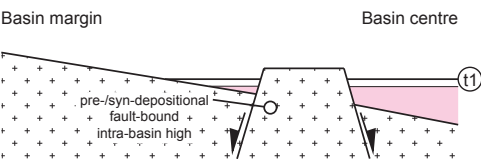

Time 2

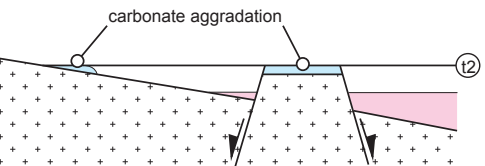

Time 3 


\begin{tabular}{|c|c|c|c|c|c|c|c|c|}
\hline $\begin{array}{l}\text { Well } \\
\text { name }\end{array}$ & Well-log data & TD (m) & $\begin{array}{l}\text { ZSG Thickness } \\
\text { (m) }\end{array}$ & $\begin{array}{c}\text { Fully } \\
\text { penetrate the } \\
\text { ZSG? } \\
\end{array}$ & Halite proportion & $\begin{array}{c}\text { Inferred } \\
\text { Depositional } \\
\text { Zone (DZ) } \\
\end{array}$ & Structural location & Comment \\
\hline $15 / 5-3$ & GR, RHOB, DT & 5042 & 1046 & Yes & $93 \%$ & 4 & South Viking Graben; deep basin & Penetrates off-centre of salt diapir \\
\hline $16 / 4-1$ & GR, RHOB, DT & 2909 & 191 & Yes & - & 1 & Utsira High; basin margin & Located $4 \mathrm{~km} \mathrm{SE}$ of salt diapir \\
\hline $15 / 9-9$ & GR, RHOB, DT & 3044 & 45 & Yes & - & 1 & Sleipner Terrace; basin margin & \\
\hline $15 / 12-3$ & GR, RHOB, DT & 4450 & 1203 & Yes & $71 \%$ & 3 & Ling Graben; intra-basin terrace & Penetrates off-centre of salt diapir \\
\hline $15 / 12-2$ & GR, RHOB, DT & 2924 & $37+$ & No & - & $3 ?$ & Ling Graben; intra-basin terrace & Penetrates crest of salt diapir \\
\hline $15 / 9-16$ & GR, RHOB, DT & 3120 & 55 & Yes & - & 1 & Sleipner Terrace; basin margin & - \\
\hline $15 / 9-13$ & GR, RHOB & 3280 & $25+$ & No & - & $1 ?$ & Sleipner Terrace; basin margin & - \\
\hline $16 / 7-3$ & GR, RHOB, DT & 3116 & 64 & Yes & - & 1 & Sleipner Terrace; basin margin & - \\
\hline $16 / 8-2$ & GR, DT & 3585 & $1325+$ & No & $94 \%$ & 4 & Ling Graben; deep basin & Penetrates off-centre of salt diapir \\
\hline $16 / 9-1$ & GR, DT & 3340 & $140+$ & No & $35 \%$ & $2 ?$ & Ling Graben; intra-basin terrace & - \\
\hline $25 / 10-4 R$ & GR, RHOB, DT & 2550 & $49+$ & No & - & 1 & Utsira High; basin margin & - \\
\hline $25 / 10-2 R$ & GR, RHOB, DT & 3153 & 126 & Yes & - & 1 & Utsira High; basin margin & - \\
\hline $16 / 1-2$ & GR, RHOB, DT & 2918 & 96 & Yes & - & 1 & Utsira High; basin margin & - \\
\hline $16 / 7-2$ & GR, RHOB, DT & 3146 & 107 & Yes & - & 1 & Utsira High; basin margin & - \\
\hline $16 / 10-1$ & GR, RHOB, DT & 3151 & $35+$ & No & $66 \%$ & 3 & Ling Graben; deep basin/intra-basin terrace & Penetrates off-centre of salt diapir crest \\
\hline 16/11-1S & GR, RHOB, DT & 3050 & $794+$ & No & $99 \%$ & 4 & Ling Graben; deep basin/intra-basin terrace & Penetrates centre of salt diapir \\
\hline 17/11-1 & GR, RHOB, DT & 3270 & $755+$ & No & $78 \%$ & 3 & Ling Graben; intra-basin terrace & Penetrates off-centre of low-relief salt pillow \\
\hline $17 / 12-2$ & GR, RHOB, DT & 2334 & 57 & Yes & - & 1 & Sele High; basin margin & - \\
\hline 17/12-1R & GR, RHOB, DT & 4298 & $165+$ & No & $69 \%$ & 3 & Egersund Basin; deep basin & Penetrates off-centre of low-relief salt pillow \\
\hline $10 / 7-1$ & GR, DT & 1890 & 43 & Yes & - & 1 & Lista Fault Block Complex; intra-basin terrace & - \\
\hline $10 / 8-1$ & GR, RHOB, DT & 2861 & $36+$ & No & $61 \%$ & 3 & Lista Fault Block Complex; intra-basin terrace & Penetrates crest of salt pillow \\
\hline $10 / 5-1$ & GR, RHOB, DT & 1842 & $245+$ & No & - & 1 & Lista Fault Block Complex; basin margin & Penetrates off-centre of salt diapir crest \\
\hline
\end{tabular}

Table 1 
Table 2

\begin{tabular}{|c|c|c|c|}
\hline Lithology & $\begin{array}{c}\text { gamma-ray (GR) } \\
(\mathbf{A P I})\end{array}$ & $\begin{array}{c}\text { density (RHOB) } \\
\left(\mathbf{g} / \mathbf{m}^{\mathbf{3}}\right)\end{array}$ & $\begin{array}{c}\text { velocity (DT) } \\
(\boldsymbol{\mu s} / \mathbf{f t})\end{array}$ \\
\hline carnallite & $100-150(220)$ & $2.2 .2(1.57)$ & $58-70(\mathrm{~N} / \mathrm{A})$ \\
\hline halite & $0-30(0)$ & $1.9-2.3(2.04)$ & $65-73(67)$ \\
\hline anhydrite & $0-70(0-12)$ & $2.7-3.1(2.98)$ & $49-58(50)$ \\
\hline carbonate & $40-50(12-100)$ & $2.3-2.9(2.85)$ & $48-90(44)$ \\
\hline silt/sandstone & $35-60(0)$ & $2.35-2.9(2.04)$ & $55-88(67)$ \\
\hline claystone & $10-250(24-1000)$ & $1.6-2.95(2.65-2.7)$ & $48-90(60-170)$ \\
\hline
\end{tabular}

